\title{
Spatial variations in antigorite fabric across a serpentinite subduction channel: Insights from the Ohmachi Seamount, Izu-Bonin frontal arc
}

Ken-ichi HIRAUCHI ${ }^{1}$, Katsuyoshi MICHIBAYASHI ${ }^{2}$, Hayato UEDA $^{3}$, and Ikuo KATAYAMA ${ }^{1}$

${ }^{1}$ Department of Earth and Planetary Systems Science, Graduate School of Science, Hiroshima University, 1-3-1 Kagamiyama, Higashi-Hiroshima, Hiroshima 739-8526, Japan

${ }^{2}$ Institute of Geosciences, Shizuoka University, Shizuoka 422-8529, Japan

${ }^{3}$ Faculty of Education, Hirosaki University, 1 Bunkyo-cho, Hirosaki, Aomori 036-8560, Japan

Corresponding author: Ken-ichi HIRAUCHI

Phone: +81-82-422-7111

Fax: $+81-82-424-0735$

E-mail: k-hirauchi@hiroshima-u.ac.jp

Keywords: antigorite, crystal-preferred orientation, mantle wedge, seismic anisotropy, serpentinite, subduction zone. 


\section{ABSTRACT}

We conducted a microstructural study of samples from a natural serpentinite shear zone 3 in the Ohmachi Seamount, Izu-Bonin frontal arc. The serpentinite samples consist mainly of

4 columnar antigorite grains that show marked variations in texture from two approximately 5 orthogonal sets of grains (interpenetrating) to aligned (schistose) forms. Because the two 6 types of grains have similar compositions, these textural differences are interpreted to reflect 7 the existence of a strain gradient toward a plate interface in a subduction zone. The crystal8 preferred orientation (CPO) of antigorite with interpenetrating texture is almost randomly 9 oriented, whereas in the case of schistose texture the CPO shows a typical [010](001) pattern.

10 We also found that with increasing intensity of schistosity, the polarization plane of $V \mathrm{~s}_{1}$ for 11 antigorite grains becomes aligned parallel to the flow plane, consistent with a plane oriented 12 normal to the maximum concentration of slow antigorite $c$-axes. This configuration results in 13 seismic anisotropy that is approximately five times higher than that for olivine grains. These 14 findings indicate that if a serpentinite layer on the plate interface attains large bulk shear 15 strains $(\gamma>\sim 2)$, the resultant alignment of antigorite grains within the layer strongly 16 influences the orientation and magnitude of seismic anisotropy in the mantle wedge, 17 depending on the dip angle of the subducting slab. 
Seismic anisotropy in the Earth's upper mantle is primarily attributed to the deformationinduced preferred orientation of anisotropic minerals such as olivine and orthopyroxene (Christensen, 1984; Mainprice and Silver, 1993; Zhang and Karato, 1995; Zhang et al., 2000). Consequently, the orientation and magnitude of anisotropy is central to understanding the flow geometry and style of deformation in the upper mantle. Measurements of shear-wave splitting, an unambiguous indicator of anisotropy (Long and Silver, 2009), yield the polarization direction of the fast shear wave and the delay time between the fast and slow shear waves (Savage, 1999).

Observations of shear-wave splitting have been carried out for most subduction zones, revealing a wide range of splitting behaviors (Wiens et al., 2008); for example, the direction of fast shear-wave polarization rotates from convergence-normal in areas close to the trench to convergence-parallel farther from the trench (Smith et al., 2001; Nakajima and Hasegawa, 2004; Kneller and van Keken, 2007; Pozgay et al., 2007; Hoernle et al., 2008). Several explanations have been proposed for the development of trench-parallel anisotropy beneath the fore-arc (or arc): deformation of water-rich olivine (Jung and Karato, 2001), aligned meltpockets (Holtzman et al., 2003), small-scale convection driven by foundering of the arc lower crust (Behn et al., 2007), and trench-parallel flow caused by oblique subduction, slab rollback, or along-strike variations in slab geometry (Smith et al., 2001; Mehl et al., 2003; Kneller and van Keken, 2007). Here, we focus on splitting data collected from local slab earthquakes, as such data constrain the nature of seismic anisotropy in the mantle wedge, whereas the teleseismic ray paths sample the wedge as well as the slab itself and subslab mantle (Long and van der Hilst, 2006).

A large amount of water is liberated from subducting oceanic crust by pressure- and temperature-controlled dehydration reactions, thereby hydrating the overriding mantle wedge and causing serpentinization (Hyndman and Peacock, 2003). Recent seismic observations have documented highly resolved, low-velocity anomalies in the mantle wedge, strongly indicating the presence of serpentine (e.g., Kamiya and Kobayashi, 2000; Bostock et al., 2002; DeShon and Schwartz, 2004; Matsubara et al., 2008). Serpentine minerals (lizardite, chrysotile, and antigorite) are hydrous phyllosilicates $\left(\sim 13 \mathrm{wt} \% \mathrm{H}_{2} \mathrm{O}\right)$, representing a possibly important water reservoir in subduction zones (Schmidt and Poli, 1998). Lizardite and chrysotile are only stable at temperatures below $\sim 300{ }^{\circ} \mathrm{C}$ (Evans, 2004), whereas antigorite is 
zone environments (Ulmer and Trommsdorff, 1995; Bromiley and Pawley, 2003; Komabayashi et al., 2005). Kern et al. (1997) and Watanabe et al. (2007) reported that Pwave and S-wave velocities in foliated antigorite serpentinite propagate slowest in a direction normal to the foliation plane (parallel to the antigorite $c$-axis), and that antigorite serpentinite has a seismic anisotropy approximately five times stronger than that of olivine-dominated rocks. Bezacier et al. (2010) determined the elastic constants of antigorite using Brillouin spectroscopy under ambient conditions, attaining high P-wave and S-wave anisotropies (46\% and $66 \%$, respectively) for single-crystal antigorite.

Recent deformation experiments under conditions corresponding to the mantle wedge have revealed that the slow $c$-axis of antigorite crystals tends to rotate to an orientation normal to the shear plane during deformation, resulting in seismic anisotropy for an aggregate of antigorite that is an order of magnitude stronger than that for an aggregate of olivine (Katayama et al., 2009). Thus, antigorite in the hydrated forearc mantle may play an important role in controlling the orientation and magnitude of seismic anisotropy (Watanabe et al., 2007; Kneller et al., 2008; Katayama et al., 2009; Mainprice and Ildefonse, 2009; Bezacier et al., 2010; Boudier et al., 2010); however, natural examples of antigorite CPO are largely unknown, with the exception of several local examples (Bezacier et al., 2010; Soda and Takagi, in press), despite the reported occurrence of a coherent body of highly foliated antigorite serpentinites with a mantle wedge origin (Nozaka, 2005; Hirauchi, 2006).

In the present paper, we report the results of analyses of peridotites and serpentinites collected from the base of the western wall of the Ohmachi Seamount in the Izu-Bonin frontal arc, where the Pacific plate is subducting beneath the Philippine Sea plate (Figs. 1 and 2). The samples were retrieved using the submersible Shinkai 6500 of the Japan Agency for MarineEarth Science and Technology (JAMSTEC). The serpentinites show a wide variety of textures and fabrics associated with abundant antigorite, indicating the occurrence of varied metamorphic and deformation processes in a subduction zone setting. We analyzed antigorite fabrics, mineral composition, and rock texture in order to understand how, after hydration of the original peridotite, the aggregate of antigorite evolved with increasing strain to produce a significant CPO that is consistent with the strong trench-parallel seismic anisotropy in the mantle wedge.

\section{Tectonic setting}


The Ohmachi Seamount is located at $29^{\circ} 0^{\prime}-30^{\prime} \mathrm{N}, 140^{\circ} 35^{\prime}-55^{\prime} \mathrm{E}, \sim 20 \mathrm{~km}$ east of the volcanic front of the Izu-Bonin-Mariana intra-oceanic arc, the eastern margin of the Philippine Sea plate (Fig. 1a). The Philippine Sea plate consists of active and remnant island arcs and backarc basins (Karig, 1971). The Izu-Bonin-Mariana subduction system, which was initiated in the Early or Middle Eocene as the result of westward subduction of the Pacific plate (Stern and Bloomer, 1992; Bloomer et al., 1995), comprises Eocene to Miocene remnant arcs (Kyushu-Palau Ridge and West Mariana Ridge), post-Miocene backarc basins (Shikoku and Parece Vela basins and the Mariana Trough), and the active Izu-Bonin-Mariana arc. Before post-Miocene backarc opening, the Ohmachi Seamount was located within the Eocene volcanic field, whose remnants are the present-day Izu-Bonin-Mariana forearc and KyushuPalau Ridge (Stern et al., 2003).

The Ohmachi Seamount consists mainly of Late Eocene to Early Oligocene andesite and Early Miocene turbidites (Nishimura, 1992; Yuasa et al., 1998, 1999), and is terminated to the west by a normal fault of a Quaternary rift system (Fig. 1b). Serpentinite is exposed along the base of the fault scarp, overlain by andesite and turbidites. These stratigraphic relationships suggest that the serpentinite body was exhumed during the early stages of development of the Izu-Bonin-Mariana arc system (Ueda et al., 2004). Niida et al. (2001, 2003) reported that lherzolitic peridotites from the serpentinite body originated from a low degree of melting or melt refertilization of depleted mantle peridotites. Ueda et al. (2004) reported a piece of garnet-zoisite amphibolite float obtained from the northernmost part of the serpentinite body that had been subducted to eclogite-facies conditions $\left(T=600-700{ }^{\circ} \mathrm{C}, P=\sim 2 \mathrm{GPa}\right)$.

In April 2008, the northern and central parts of the N-S trending serpentinite body (Fig. 1B) were explored during five dives (6k\#1064-1068) made by the submersible Shinkai 6500 during cruise YK08-05 by the R/V Yokosuka, in order to collect rock samples through submersible-based geological observations. For example, as part of dive 6k\#1066 (observer: K.H.), we crossed the western flank of the Ohmachi Seamount in water depths of 3500-3200 $\mathrm{m}$ (Fig. 2), collecting samples at seven stations (S1-S7 in Fig. 2). At $3450 \mathrm{~m}$ depth, Quaternary sediments (clays and calcareous silts) are deposited on the sea floor (S1 in Fig. 2). At 3415-3350 m depth, cliff exposures are dominated by schistose antigorite serpentinites that strike N-S and dip steeply to the east (S2-S4, S7 in Fig. 2), and that are associated with minor lizardite/chrysotile serpentinites. Talus deposits, including cobbles of massive antigorite serpentinites, cover the slope at 3310-3275 m depth (S5 in Fig. 2). Above $3240 \mathrm{~m}$ depth, volcanic rocks (andesite and dacite) are widely exposed on the western flank of the 
seamount (S6 in Fig. 2). We also collected a cobble of lizardite/chrysotile serpentinite at 3235 m depth.

\section{Peridotite and serpentinite from the Ohmachi Seamount}

\subsection{Petrography}

The ultramafic rocks of the Ohmachi Seamount consist of residual peridotite (lherzolite or harzburgite), dunite, wehrlite, and clinopyroxenite, although they are so strongly altered that it is difficult to estimate their modal (mineral) compositions. In particular, olivine and pyroxene are extensively serpentinized in the residual peridotites collected in the present study; however, Niida et al. (2001) made the preliminary observation that spinel lherzolites from the seamount show a protogranular texture. The lherzolite consists dominantly of coarse olivine grains (up to $1 \mathrm{~cm}$ in size) with anhedral orthopyroxene and clinopyroxene (Niida et al., 2001). Most anhedral (vermicular) spinel grains $(0.2-2.0 \mathrm{~mm}$ ) are completely replaced by $\mathrm{Cr}$ magnetite surrounded by a corona of chlorite.

The wehrlite and clinopyroxenite, which show a coarse-grained cumulus texture, contain euhedral to subhedral clinopyroxene (diopside) $(0.5-3.0 \mathrm{~mm}$ in size) with interstitial olivine crystals (up to $4 \mathrm{~mm}$ in size) that show a prominent cleavage (Fig. 3A) (= cleavable olivine; Ohara and Ishii, 1998). Altered spinel grains (0.1-1.5 $\mathrm{mm}$ in size) are euhedral to subhedral. One dunite sample contains small chromitite pods.

In the ultramafic rocks, pargasitic amphibole (edenite), a hydrous phase in the upper mantle (Jenkins, 1983), occurs locally as an accessory phase interstitial to clinopyroxene and olivine. Tremolite occurs as relatively coarse-grained (up to $1 \mathrm{~mm}$ in size), acicular to prismatic grains, crosscut by antigorite.

Serpentine minerals (lizardite, chrysotile, and antigorite) were identified by laser Raman spectroscopy, based on a comparison with the data reported by Rinaudo et al. (2003) and Auzende et al. (2004). Most olivine and pyroxene grains have been directly replaced by antigorite, a high-temperature serpentine species (Fig. 3A) (Evans, 2004). Antigorite crystals are euhedral to subhedral, and $0.1-1.5 \mathrm{~mm}$ in length. Some antigorite-bearing samples show a typical interpenetrating texture (Wicks and Whittaker, 1977) (Fig. 3B), characterized by randomly oriented antigorite blades accompanied by magnetite grains with irregular outlines. This mode of occurrence indicates the irregular replacement of primary minerals under static conditions (Maltman, 1978). Some pyroxenes are completely altered to antigorite, occurring as bastite pseudomorphs (Wicks and Whittaker, 1977). 
Most of the antigorite serpentinites are strongly foliated, indicative of antigorite schist. The foliation and lineation are defined by aligned antigorite blades, and elongate ribbons and tails of fine-grained aggregates of magnetite that occur around spinel porphyroclasts.

150

151

152

153

154

155

156

157

158

159

160

161

162

163

164

165

166

167

168

169

170

171

172

173

174

175

176

177

178 Antigorite blades that show interpenetrating texture appear to be crosscut by aligned antigorite blades (herein referred to as schistose antigorite); some of the areas of interpenetrating texture occur as lens-shaped relics aligned parallel to the schistosity (Fig. 3C).

Relict olivine grains occur as rigid porphyroclasts surrounded by the antigorite matrix (Fig. 3D). Elongate porphyroclasts of bastite are aligned parallel to the schistosity (Fig. 3E), as are needle-shaped grains of secondary clinopyroxene (Fig. 3F). The foliation is overprinted by open microfolds, and a weak crenulation cleavage is developed in the limbs of microfolds (Fig. 3G). The antigorite serpentinites are also characterized by an abundance of chlorite that appears to be overgrown by antigorite (Fig. $3 \mathrm{H}$ ).

Olivine and pyroxene grains that survived the high-temperature, antigorite serpentinization are commonly retrogressively serpentinized to lizardite and chrysotile (Fig. 3D, I), a low-temperature serpentine species (Evans, 2004), forming mesh texture (rims and cores) and bastite (Wicks and Whittaker, 1977), respectively. Calcite and chrysotile occur mainly as late-stage fracture fill within the serpentinite samples.

\subsection{Mineral Chemistry}

Major-element analyses of minerals were performed using an electron probe microanalyzer (EPMA; JEOL JXA-8200) housed at the Natural Science Center for Basic Research and Development (N-BARD), Hiroshima University, Japan, with settings of $15 \mathrm{kV}$ accelerating voltage, $15 \mathrm{nA}$ beam current, and 2-4 $\mu \mathrm{m}$ beam size. The ZAF method was employed for matrix corrections. Representative analyses are listed in Supplementary Table 1.

The forsterite (Fo) and $\mathrm{NiO}$ contents of olivine grains vary from 88.2 to $90.7 \mathrm{wt} \%$ and from 0.29 to $0.44 \mathrm{wt} \%$, respectively. The $\mathrm{Mg} \#\left[=\mathrm{Mg} /\left(\mathrm{Mg}+\mathrm{Fe}^{2+}\right)\right.$ atomic ratio $]$ and $\mathrm{Al}_{2} \mathrm{O}_{3}$ content of primary clinopyroxene range from 0.913 to 0.927 and from 0.97 to $1.79 \mathrm{wt} \%$, respectively. Secondary clinopyroxene differs from primary clinopyroxene in having higher $\mathrm{SiO}_{2}$ and $\mathrm{CaO}$ contents and lower $\mathrm{TiO}_{2}, \mathrm{Al}_{2} \mathrm{O}_{3}, \mathrm{Cr}_{2} \mathrm{O}_{3}$, and $\mathrm{FeO}$ contents (Supplementary Table 1). The $\mathrm{Cr} \#[=\mathrm{Cr} /(\mathrm{Cr}+\mathrm{Al})$ atomic ratio $]$ and $\mathrm{Mg} \#$ of spinels in the residual peridotite range from 0.19 to 0.20 and from 0.66 to 0.69 , respectively. The transformation from spinel to Cr-magnetite involved a reduction in $\mathrm{Al}_{2} \mathrm{O}_{3}, \mathrm{Cr}_{2} \mathrm{O}_{3}$, and $\mathrm{MgO}$ contents, and an increase in $\mathrm{TiO}_{2}$ and $\mathrm{FeO}$ contents (Supplementary Table 1). All the analyzed amphiboles are calcic 
amphiboles; some display zoning comprising an edenitic hornblende core and tremolite rim. Tremolite grains differ from the tremolite rims in having higher $\mathrm{Al}_{2} \mathrm{O}_{3}, \mathrm{FeO}, \mathrm{Na}_{2} \mathrm{O}$, and $\mathrm{K}_{2} \mathrm{O}$ contents, and lower $\mathrm{SiO}_{2}$ and $\mathrm{CaO}$ contents (Supplementary Table 1).

The measured serpentine compositions are plotted in $\mathrm{Si}-\mathrm{Al}$ (Fig. 4a) and $\mathrm{Cr}-\mathrm{Al}$ (Fig. 4b) binary diagrams, and in a Mg-Al-Si ternary diagram (Fig. 5). Lizardite and chrysotile occur mainly as mesh texture (rims and cores) and bastite. These pseudomorphic serpentines strongly reflect the compositional variations among the parent silicates. Serpentine in both rims and cores is characterized by a high $\mathrm{Mg} / \mathrm{Si}$ ratio (1.43-1.59) and a low $\mathrm{Al}_{2} \mathrm{O}_{3}$ content (0.00-0.77 wt\%). Serpentines in bastite have a low $\mathrm{Mg} / \mathrm{Si}$ ratio (1.19-1.37) and a high $\mathrm{Al}_{2} \mathrm{O}_{3}$ content (1.08-2.25 wt\%), possibly reflecting the lower $\mathrm{Mg}$ and higher $\mathrm{Al}$ contents of pyroxene compared with olivine (Supplementary Table 1), and contain minor $\mathrm{CaO}, \mathrm{Cr}_{2} \mathrm{O}_{3}$, and $\mathrm{TiO}_{2}$.

Antigorite has higher $\mathrm{SiO}_{2}$ contents (39.6-43.0 wt\%) and lower $\mathrm{H}_{2} \mathrm{O}(12.2-14.4 \mathrm{wt} \%)$ and $\mathrm{MgO}(37.1-40.0 \mathrm{wt} \%)$ contents than do lizardite and chrysotile, reflecting differences in the structural formulae of these species (Dungan, 1974). The antigorite grains have $\mathrm{Mg} / \mathrm{Si}$ ratios of 1.35-1.46 and do not inherit the compositions of the parent silicates (Supplementary Table 1). The interpenetrating and schistose antigorites have similar compositions and variable $\mathrm{Al}_{2} \mathrm{O}_{3}$ contents $(0.56-4.54 \mathrm{wt} \%)$, indicating coupled Al-substitution in tetrahedral and octahedral sites (Fig. 5). With increasing $\mathrm{Al}_{2} \mathrm{O}_{3}$ content, the composition of antigorite appears to be linearly continuous with that of chlorite in a $\mathrm{Mg}-\mathrm{Al}-\mathrm{Si}$ diagram (Fig. 5). Finally, the $\mathrm{Al}_{2} \mathrm{O}_{3}$ content of antigorite increases slightly with increasing $\mathrm{Cr}_{2} \mathrm{O}_{3}$ content (Fig. 4b).

\subsection{Fabric analysis}

To examine the development of anisotropy within the antigorite serpentinite, we selected for analysis three representative samples (\#1065R006, \#1064R012, and \#1066R013) with varying degrees of schistosity (massive, transitional, and schistose types, respectively; Fig. 6). We then measured the crystal-preferred orientations (CPOs) of antigorite grains in the three samples from highly polished thin sections using a scanning electron microscope equipped with an electron-backscatter diffraction (SEM-EBSD) system (JEOL JSM6300 with HKL Channel5), housed at the Centre for Instrumental Analysis, Shizuoka University, Japan. Thin sections were made in an arbitrary orientation in the massive type, and cut perpendicular to the foliation and parallel to the lineation (i.e., XZ-sections) in the other two types. We determined the crystal orientations of between 212 and 234 antigorite grains per sample (Fig. 
211 7), and visually checked the computerized indexation of the diffraction pattern for each 212 crystal orientation. To quantify the degree of CPO development, we determined the fabric 213 strength and distribution density of the principal crystallographic axes using the $J$-index and 214 pfJ index (see Ben Ismaïl and Mainprice, 1998; Mainprice et al., 2000; Michibayashi and 215 Mainprice, 2004; Michibayashi et al., 2006, 2009) and the $M$-index (see Skemer et al., 2005).

216 The massive type contains a random CPO of antigorite grains, with a weak bimodal 217 alignment of [100] and [010] axes and several clusters of [001] axes (Fig. 7A). The two 218 concentrations of [010] axes are separated by $90^{\circ}$, possibly reflecting the orientations of 219 roughly orthogonally oriented antigorite blades (Fig. 6A, B). The fabric intensity ( $p f j$ index) is 220 similar among the three crystallographic axes, ranging from 1.29 to 1.39 .

221 The schistose type shows a distinct alignment of [001] axes normal to the foliation (Z), $222[010]$ axes parallel to the lineation (X), and [100] axes subnormal to the lineation and within 223 the plane of the foliation (Y); i.e., a [010](001) CPO pattern, although both the [100] and 224 [010] axes have a weak girdle distribution within the foliation (XY plane) (Fig. 7C). The fabric intensity ( $p f j$ index) of [001] axes $(p f j=5.59)$ in the schistose type is much higher than that of the $[100](p f j=2.29)$ and $[010](p f j=2.99)$ axes.

The CPO pattern for the transitional type shows scattered [100] axes with a weak alignment parallel to the $\mathrm{Y}$ direction, relatively concentrated [010] axes parallel to the lineation (X), and [001] axes with a bimodal alignment, in which one mode is normal to the foliation (Z) (similar to [001] axes in the schistose type) and the other might reflect one of the pre-existing alignments observed in the massive type (Fig. 7B). The fabric intensity ( $p f j$ index) of [001] axes $(p f j=1.40)$ is weaker than that of [010] axes $(p f j=1.63)$ but stronger than that of [100] axes $(p f j=1.27)$. The fabric strength $(J$-index and $M$-index $)$ of the schistose type $(J=14.9 ; M=0.074)$ is much higher than that of the massive $(J=4.38 ; M=0.012)$ and transitional $(J=4.61 ; M=0.011)$ types, which have similar fabric strengths (Fig. 7).

\section{Rock seismic properties}

The seismic properties of a rock mass can be computed by averaging the elastic constants of the individual grains in all directions and weighting their contribution based on the modal composition of the aggregate (Mainprice and Humbert, 1994; Mainprice et al., 2000). Given that the three samples selected for analysis (Fig. 6) are composed almost entirely of antigorite, we calculated the seismic properties assuming a composition of $100 \%$ antigorite (Fig. 8), using the elastic constants of Bezacier et al. (2010) for antigorite and the Voigt-Reuss-Hill 
averaging scheme (Mainprice et al., 2000). The P-wave anisotropy $(A V \mathrm{p})$ was calculated as a percentage using the formula $200\left(V \mathrm{p}_{\max }-V \mathrm{p}_{\min }\right) /\left(V \mathrm{p}_{\max }+V \mathrm{p}_{\min }\right)$, and the $\mathrm{S}$-wave anisotropy $(A V \mathrm{~s})$ was calculated for a specific propagation direction using the formula $200\left(V \mathrm{~s}_{1}\right.$ $\left.V \mathrm{~s}_{2}\right) /\left(V_{\mathrm{s}_{1}}+V_{\mathrm{s}_{2}}\right)$, where $V \mathrm{~s}_{1}$ and $V \mathrm{~s}_{2}$ are the fast and slow wave velocities, respectively (e.g., Pera et al., 2003).

The seismic velocities $\left(V \mathrm{p}, V_{\mathrm{s}_{1}}\right.$, and $\left.V_{\mathrm{s}_{2}}\right)$ and seismic anisotropy determined for each rock type are listed in Supplementary Table 2. Values of $V \mathrm{p}_{\max }$ range from 7.26 to $8.15 \mathrm{~km} / \mathrm{s}$ $\left(V \mathrm{p}_{\text {mean }}=7.56 \mathrm{~km} / \mathrm{s}\right), V_{\mathrm{s}_{1 \max }}$ from 4.10 to $4.55 \mathrm{~km} / \mathrm{s}\left(V_{\mathrm{s}_{1 \text { mean }}}=4.25 \mathrm{~km} / \mathrm{s}\right)$, and $V V_{\mathrm{s}_{2 \max }}$ from 3.94 to $4.09 \mathrm{~km} / \mathrm{s}\left(V_{\mathrm{s}_{2 \text { mean }}}=4.01 \mathrm{~km} / \mathrm{s}\right)$. As expected based on the CPO data, the analyzed samples show a wide range of seismic anisotropy: $A V \mathrm{p}$ ranges from 10.4 to $31.3 \%\left(A V \mathrm{p}_{\text {mean }}=\right.$ $17.6 \%)$ and $A V \mathrm{~s}$ from 8.85 to $35.99 \%\left(A V \mathrm{~s}_{\text {mean }}=18.19 \%\right)$. Note that $A V \mathrm{p}$ and $A V \mathrm{~s}$ calculated from the CPOs of 200 antigorite grains are similar to those in the bulk rock aggregate (antigorite schist) measured by ultrasonic measurements (Kern et al., 1997; Watanabe et al., 2007).

Figure 8 shows stereographic projections of $V \mathrm{p}$ and $A V \mathrm{~s}$ data, and the orientation of the polarization plane of the fastest $V \mathrm{~s}\left(V \mathrm{~s}_{1}\right)$. For the massive type, the fastest and slowest $V \mathrm{p}$ directions appear to reflect the weak concentrations of [100] and [001] axes, respectively (Fig. $8 \mathrm{~A})$. For the transitional type, $V \mathrm{p}$ is fastest parallel to the lineation $(\mathrm{X})$, which coincides with the maximum alignment of [010] axes (Fig. 8B). Vp is slowest subnormal to the foliation (Z); i.e., in a direction between the two concentrations of [001] axes. For the schistose type, $V \mathrm{p}$ is fastest subparallel to the lineation (X) and defines a girdle distribution within the plane of the foliation (XY plane); the slowest direction is normal to the foliation $(\mathrm{Z})$, resulting in an axial symmetry, with the [001] maximum as the symmetry axis (Fig. 8C).

The observed variation in polarization anisotropies reflects the measured variations in CPOs and fabric intensities (Fig. 8). Polarization anisotropies for the transitional type show a maximum birefringence $(A V \mathrm{~s})$ for propagation directions at low angles to the plane of the foliation (XY plane), whereas those for the schistose type show a maximum birefringence $(A V \mathrm{~s})$ for propagation directions subparallel to the lineation $(\mathrm{X})($ Fig. 8B, C). With increasing intensity of schistosity, the orientation of the polarization plane of $V \mathrm{~s}_{1}$ becomes parallel to the plane of the foliation (XY plane), coincident with a plane oriented normal to the maximum concentration of [001] axes (Fig. 8). 


\subsection{Metamorphic and deformation history of serpentinite from the Ohmachi Seamount}

The serpentinite samples obtained from the Ohmachi Seamount were possibly derived from the base of the mantle wedge, just above the subducting Pacific plate in an immature intra-oceanic arc system (Ueda et al., 2004). These samples provide evidence for progressive hydration involving a paragenetic sequence from $\mathrm{Ca}-\mathrm{Al}$ amphibole to tremolite, antigorite, and diopside, which is in contrast to the $P-T$ history recorded by amphibole blocks (Ueda et al., 2004, 2009).

In the lherzolitic peridotites, pargasitic amphibole is in textural equilibrium with mantle minerals. Based on experimental results (Wallace and Green, 1991; Niida and Green, 1999), the mineral assemblage of the lherzolitic peridotites, when considered in combination with the high $\mathrm{Na}_{2} \mathrm{O}$ content (up to $3.5 \%$ ) of pargasitic amphibole (Supplementary Table 1), indicates formation of the peridotites at pressures of $<2 \mathrm{GPa}$ and temperatures of $900-1075{ }^{\circ} \mathrm{C}$, assuming water-saturated conditions. The zoned amphiboles have $\mathrm{Na}_{2} \mathrm{O}$-rich pargasitic cores rimmed by $\mathrm{Na}_{2} \mathrm{O}$-poor tremolite (Supplementary Table 1), suggesting decompressional cooling (Niida and Green, 1999). It is also possible that alteration of clinopyroxene and orthopyroxene in the presence of excess $\mathrm{H}_{2} \mathrm{O}$ produced olivine and tremolite at lower temperatures $\left(<800^{\circ} \mathrm{C}\right)$ (Berman, 1986; Bucher and Frey, 2002).

Antigorite and diopside may have formed from the hydration of olivine and tremolite in the case that aqueous fluids released by dehydration of the subducting slab were added to the overlying peridotite. Because this hydration event lacks a mineral assemblage of antigorite and brucite, it involved temperatures of $450-575{ }^{\circ} \mathrm{C}$ for $P_{\text {total }}=P\left(\mathrm{H}_{2} \mathrm{O}\right)=1 \mathrm{GPa}$ (Berman, 1986; Bucher and Frey, 2002). Since the $\mathrm{Al}_{2} \mathrm{O}_{3}$ and $\mathrm{Cr}_{2} \mathrm{O}_{3}$ contents of antigorite tend to vary sympathetically, the $\mathrm{Al}(\mathrm{Cr})$ in antigorite may have been supplied directly from the breakdown of spinel or from chlorite coronas that formed around altered spinel grains.

High-temperature serpentinization in the overlying mantle wedge initially occurred under near-static conditions, as indicated by the interpenetrating antigorite blades (Fig. 3B). However, the close compositional relationship between the interpenetrating and schistose antigorite grains indicate that after the formation of antigorite in the mantle wedge, the hydrated region was immediately deformed, given that its viscosity is lower than that of olivine (Hilairet et al., 2007). Therefore, we suggest that the textural differences among the analyzed antigorite rocks reflect the existence of a strain gradient toward the plate interface. Indeed, the outcrops from which antigorite schist was sampled are located close to 
amphibolite blocks (Ueda et al., 2004) that represent the remains of ancient subducted oceanic crust.

309 In a subduction zone setting, simple-shear deformation is primarily induced by movement of the subducting slab. We consider that the viscosity contrast between olivine and antigorite (Hilairet et al., 2007) causes decoupling between the slab and the mantle wedge, thereby impeding asthenospheric flow within the hydrated portion of the mantle wedge (Kneller et al., 2007; Wada et al., 2008; Hilairet and Reynard, 2009). The resulting return flow within a wedge-shaped, serpentinized subduction channel, as proposed by Gerya et al. (2002), exhumed the amphibolite blocks within the matrix of the serpentinite, prior to at least the initiation of Early or Middle Eocene arc volcanism (Stern and Bloomer, 1992; Bloomer et al., 1995; Stern et al., 2003). We also note that antigorite schist observed in dive 6k\#1066 strikes $\mathrm{N}-\mathrm{S}$ and dips steeply to the east, subnormal to the surface of the present-day Pacific subducting slab. Since the antigorite schistosity and the slab surface were initially oriented parallel to each other, this finding indicates that the serpentinite layer exhumed in a fossil subduction channel were rotated by later tectonics such as post-Miocene back-arc spreading or arc volcanism, although further analysis is required to determine whether the orientation of the schistosity is consistent throughout the entire serpentinite body.

The low-temperature serpentine species appear to have formed from relict olivine and pyroxene grains at temperatures below $\sim 300{ }^{\circ} \mathrm{C}$ (Evans, 2004), during or after late-stage uplift. Pseudomorphic replacement of primary minerals by lizardite and chrysotile suggests that serpentinization occurred without concurrent deformation. maximum parallel to the flow direction (lineation) and orientation of the (001) plane parallel to the flow plane (foliation) (Fig. 7C), indicating the dominance of a single slip system: [010](001). In contrast, the CPO pattern for interpenetrating antigorite grains is characterized by a near-random orientation with a weak bimodal alignment of [100] and [010] axes (Fig. 7A), reflecting the fact that the antigorite blades are roughly oriented in two contrasting directions (Fig. 6A, B). The CPO pattern obtained for a mixture of interpenetrating and schistose antigorite grains shows that the alignment of [010] axes predated the alignment of the other two axes, thereby representing a relic feature of the preexisting, interpenetrating antigorite grains, particularly the [100] and [001] axes (Fig. 7B). In addition, the fabric 
strength of transitional type samples is not much stronger than that of the massive type (Fig. 7A, B; Fig. 9), meaning that the increased alignment of crystal axes was counterbalanced by the influence of the pre-existing CPO.

Both compressional and shear waves show relatively strong anisotropies in the massive type (11.2\% and $9.72 \%$, respectively), indicating that even if the hydration of olivine to antigorite occurs under static conditions, a considerable amount of anisotropy develops, although its direction may show no relation to flow geometry. With increasing strain, however, both $\mathrm{P}$-wave and S-wave anisotropies become parallel to the maximum alignment of [010] axes (flow direction), and the polarization plane of $\mathrm{Vs}_{1}$ becomes aligned parallel to the flow plane (Fig. 8).

The maximum P-wave and S-wave anisotropies for the schistose type are $31.3 \%$ and $35.99 \%$, respectively, approximately three times higher than those for the other two types (Fig. 8; Supplementary Table 2), meaning that the orientation and strength of seismic anisotropy in the serpentinized layer is largely controlled by the CPO of the schistose type. Although we are unable to directly measure strain from naturally deformed samples, the relationship between shear strain and seismic anisotropy ( $A V \mathrm{p}$ and $A V \mathrm{~s}$ ) in experimentally deformed specimens (Katayama et al., 2009) indicates that large bulk shear strains (at least $\gamma>\sim 2$ ) are required to produce the significant CPO pattern observed in the schistose type by erasing the earlier CPO pattern observed in the massive type (Fig. 9). Given that a low-viscosity serpentinized layer upon a subducting plate interface produces strain localization within the layer and subsequent large bulk shear strains (Hilairet et al., 2007; Wada et al., 2008; Hilairet and Reynard, 2009), the above results indicate that the strongly anisotropic serpentinite layer dominates the base of the hydrated mantle wedge.

The CPO patterns obtained for the schistose type in the present study and a natural sample reported by Soda and Takagi (in press) reveal an alignment of $a$-axes normal to the lineation and within the plane of the foliation (Fig. 7c), whereas a pattern obtained for a natural sample reported by Bezacier et al. (2010) reveals an alignment of $a$-axes parallel to the flow direction (lineation), indicating that in the case of antigorite, at least two slip systems are activate in nature; i.e., [010](001) and [100](001). We suggest that the above discrepancy in terms of $a$ axis orientation reflects differences in the physical and chemical environments during deformation. For example, the slip system in olivine is known to change with pressure, temperature, stress, and water content (e.g., Jung and Karato, 2001; Jung et al., 2006, 2009; Katayama and Karato, 2006, 2008). Although the experimentally deformed specimens 
372 showed that the antigorite $a$-axis becomes oriented parallel to the flow direction in a 373 laboratory environment at a pressure of $1 \mathrm{GPa}$ and temperature of $300-400^{\circ} \mathrm{C}$ (Katayama et 374 al., 2009), further deformation experiments performed under different physical and chemical 375 conditions are required to determine the cause of a change in slip system within antigorite. 376 However, because only minor variations in seismic velocity exist between the $a$ - and $b$-axes 377 (Mainprice and Ildefonse, 2009; Bezacier et al., 2010), seismic anisotropy produced by the 378 CPO of antigorite could be controlled mainly by the orientation of $c$-axes.

379 Boudier et al. (2010) proposed that antigorite nucleates on particular planar defects in 380 olivine within the host peridotite, resulting in an antigorite schistosity. However, the antigorite 381 CPO in the schistose type shows no geometric relationship with the orientation of planar 382 defects in olivine, because it developed by overprinting the pre-existing antigorite CPO in the 383 massive type.

\subsection{Implications for seismic anisotropy in subduction zones}

In subduction zone settings, assuming simple corner flow controlled by viscous coupling between the subducting slab and the overriding plate, trench-perpendicular anisotropy beneath the back-arc (or arc) is likely to correspond to A-type (or similar) olivine fabric in the mantle wedge (Hall et al., 2000), in which the fast $a$-axis of olivine crystals is preferentially aligned with the flow direction under water-poor conditions and high temperature/low stress (Zhang and Karato, 1995; Jung et al., 2006). Deformation experiments have shown that under waterrich conditions and low temperature/high stress, olivine deforms by (010)[001] slip that produces a B-type fabric; i.e., the fast olivine $a$-axis becomes oriented perpendicular to the flow direction (Jung and Karato, 2001). Because such conditions (suitable for the development of B-type olivine fabric) may be present in parts of the mantle wedge, transitions in olivine fabric may explain the occurrence of trench-parallel fast directions in the mantle wedge beneath the fore-arc (or arc), as observed at northeastern Japan and Ryukyu, where wedge flow is predicted to be dominated by slab-driven 2D corner flow (Nakajima and 398 Hasegawa, 2004; Mizukami et al., 2004; Kneller et al., 2005; Lassak et al., 2006; Long and 399 van der Hilst, 2006; Tasaka et al., 2008; Katayama, 2009). It has also been proposed that trench-parallel flow, combined with an A-type (or similar) olivine fabric, provides an alternative explanation of trench-parallel anisotropy in the mantle wedge. Long and Silver (2008) proposed that trench-parallel anisotropy in the mantle wedge observed at Tonga is 
associated with rapid slab rollback (Kincaid and Griffiths, 2003) favor the development of an A-type (or similar) olivine fabric rather than B-type.
Despite the fact that the delay time depends on the thickness of the anisotropic layer and its magnitude of anisotropy, it shows marked spatial variations. For example, delay time is $\sim 0.1-0.2 \mathrm{~s}$ in northeast Japan and $\sim 1-2 \mathrm{~s}$ at Ryukyu, Izu-Bonin, and Tonga (Smith et al., 2001; Nakajima and Hasegawa, 2004; Anglin and Fouch, 2005; Long and van der Hilst, 2006). Katayama (2009) showed that the short delay time recorded in northeast Japan is consistent with the occurrence of a thin anisotropic layer $(\sim 10-20 \mathrm{~km})$ caused by the crystalpreferred orientation (CPO) of olivine (B-type fabric); however, the longer delay time observed at Ryukyu, Izu-Bonin, and Tonga cannot be explained in terms of the CPO of olivine, because in such a case the calculated anisotropic layer $(\sim 100-200 \mathrm{~km})$ would be thicker than the entire mantle wedge sampled by local S waves (Katayama et al., 2009).

Recent deformation experiments revealed that with increasing shear strain, the slow antigorite $c$-axis becomes oriented perpendicular to the flow plane, resulting in seismic anisotropy for antigorite crystals that is an order of magnitude stronger than that for olivine crystals (Katayama et al., 2009). Bezacier et al. (2010) measured the CPO of antigorite crystals in a natural sample from the Escambray massif (central Cuba) using SEM-EBSD, revealing that the seismic anisotropy $\left(36.8 \%\right.$ for $A V \mathrm{p}_{\max }$ and $50.52 \%$ for $\left.A V \mathrm{~s}_{\max }\right)$ is higher than that in the experimentally deformed samples reported by Katayama et al. (2009) (25.8\% for $A V \mathrm{p}_{\max }$ and $26.27 \%$ for $A V \mathrm{~s}_{\max }$ ).

For the three samples from the Ohmachi Seamount described in the present study, both Pand S-waves show strong anisotropies (up to $31.3 \%$ and $35.99 \%$, respectively) in the schistose type, similar to the values reported for the sample from the Escambray massif (see above); consequently, the large delay times recorded at Ryukyu, Izu-Bonin, and Tonga are consistent with the occurrence of a thin anisotropic layer $(\sim 10-20 \mathrm{~km})$ caused by the CPO of antigorite. However, we consider that a thicker anisotropic layer is necessary to achieve large delay times of $\sim 1-2 \mathrm{~s}$, because in the serpentinite layer located far from the plate interface, which is expected to record only low bulk strains, the CPO for the massive type might have a strong effect in terms of weakening the significant seismic anisotropy represented by the CPO in the schistose type, which is controlled mainly by flow geometry.

As mentioned above, recent seismic observations have revealed that serpentinite is formed through the hydration of peridotite by aqueous fluids expelled upward from the subducting slab (Hyndman and Peacock, 2003). In such regions, the (001) plane of antigorite is 
preferentially aligned with the plate interface as a result of simple-shear deformation induced by movement of the subducting slab (Katayama et al., 2009). Given that local S-waves propagate in a near-vertical direction in subduction zones with a steeply subducting slab (e.g., Ryukyu, Izu-Bonin, and Tonga), the significant contribution of the slow antigorite $c$-axis, which is oriented normal to the surface of the slab, results in the polarization direction of the fast shear wave being oriented parallel to the trench axis (Katayama et al., 2009). Furthermore, even if trench-parallel flow is dominant in the mantle wedge, as inferred at Izu-Bonin and Tonga (Anglin and Fouch, 2005; Long and Silver, 2008), the slow antigorite $c$-axis remains oriented normal to the steeply subducting slab, thereby producing a strong trench-parallel anisotropy in the mantle wedge. In contrast, in subduction zones with a shallowly dipping slab (e.g., southwest Japan and Cascadia), a weak trench-parallel anisotropy is observed with delay times of $\sim 0.3-0.5 \mathrm{~s}$ (Cassidy and Bostock, 1996; Currie et al., 2001; Salah et al., 2008), despite the fact that a high degree of mantle wedge serpentinization $(\sim 70-80 \%)$ is suggested by the existence of low-velocity anomalies (Bostock et al., 2002; Ramachandran et al., 2005; Matsubara et al., 2008). This weak anisotropy possibly reflects a small contribution by slow antigorite $c$-axes to near-vertically propagating waves due to the shallow dip of the slab, although the delay time for local S-waves generally depends on ray path length through the mantle wedge, which becomes shorter with decreasing slab dip (Long and Silver, 2008).

In summary, the wide range of dip angles of subducting slabs, possibly reflecting the age 456 of the slab, and range in bulk shear strains and thickness of the serpentinite layer may explain the variable strength of trench-parallel seismic anisotropy observed in the mantle wedge.

\section{Conclusions}

We studied mantle-wedge peridotites and serpentinites collected during five dives (6k\#1064-1068) of the submersible Shinkai 6500 during cruise YK08-05 in 2008 at the base of the western wall of the Ohmachi Seamount in the Izu-Bonin frontal arc. Olivine and pyroxene within the peridotites are directly replaced by antigorite, a high-temperature serpentine species. Some antigorite-rich samples show interpenetrating (massive), orthogonally oriented antigorite grains, although most samples are characterized by schistose, aligned antigorite grains that crosscut the interpenetrating grains. The two sets of grains have similar compositions, indicating that the textural differences reflect the existence of a strain gradient toward the interface of a subducting plate. 
To understand the development of anisotropy within aggregates of antigorite, we measured the crystal-preferred orientations (CPOs) of antigorite grains in three selected samples that vary in terms of the degree of schistosity (massive, transitional, and schistose types). The CPO for the massive type is almost randomly oriented, whereas that for the schistose type is characterized by a [010] maximum parallel to the flow direction (lineation) and orientation of the (001) plane parallel to the flow plane (foliation). The transitional type has a fabric strength similar to that of the massive type, meaning that the increasing alignment of all crystallographic axes in antigorite, possibly arising from simple shear deformation, was counterbalanced by the effect of the pre-existing CPO.

The maximum P-wave and S-wave anisotropies for the schistose type are very high (31.3\% and $35.99 \%$, respectively), approximately three times higher than those for the massive type (11.2\% and $9.72 \%$, respectively). In addition, the polarization plane of $V \mathrm{~s}_{1}$ for the schistose type is oriented parallel to the flow plane. These findings indicate that the textural transition of antigorite grains from interpenetrating to schistose forms yields much stronger anisotropy than that of olivine grains, significantly affecting the orientation and magnitude of seismic anisotropy in the mantle wedge, depending on the dip angle of the (001) plane of antigorite. For example, the strong trench-parallel anisotropy recorded at Ryukyu, Izu-Bonin, and Tonga is explained by the occurrence of a thin anisotropic layer caused by the CPO of schistose antigorite grains upon a steeply subducting slab, given the significant contribution to near-horizontally polarized S-waves of the slow antigorite $c$-axis.

\section{Acknowledgements}

We would like to thank the captain, crew, and scientists of the R/V Yokosuka and the Shinkai 6500 team for their assistance and professional work. Discussions with the scientific party during cruise YK08-05 contributed to the ideas expressed in this paper. We also thank K. Niida for providing peridotite samples collected during previous cruises, D. Mainprice and A. Tommasi for providing crystallographic data for serpentine, and Y. Shibata for expert technical assistance in using the electron microprobe. Figures showing CPO data and calculations of J-index and seismic anisotropy were performed using the interactive programs developed by D. Mainprice of Université Montpelier II, France. We greatly appreciate constructive comments by N. Christensen, B. Reynard, and an anonymous reviewer, as well as careful editorial handling by L. Stixrude. This study was supported by a Grant-in-Aid for JSPS Fellows awarded to K. H. by the Japan Society for the Promotion of Science. 


\section{References}

Anglin, D.K., Fouch, M.J., 2005. Seismic anisotropy in the Izu-Bonin subduction system. Geophys. Res. Lett. 32, L09307.

Auzende, A.-L., Daniel, I., Reynard, B., Lemaire, C., Guyot, F., 2004. High-pressure behaviour of serpentine minerals: a Raman spectroscopic study. Phys. Chem. Minerals 31, 269-277.

Behn, M.D., Hirth, G., Kelemen, P.B., 2007. Trench-parallel anisotropy produced by foundering of arc lower crust. Science 317, 108-111.

Ben Ismaïl, W., Mainprice, D., 1998. An olivine fabric database: an overview of upper mantle fabrics and seismic anisotropy. Tectonophysics 296, 145-157.

Berman, R.G., Engi, M., Greenwood, H.J., Brown, T.H., 1986. Derivation of internallyconsistent thermodynamic data by the technique of mathematical programming: a review with application to the system $\mathrm{MgO}-\mathrm{SiO}_{2}-\mathrm{H}_{2} \mathrm{O}$. J. Petrol. 27, 1331-1364.

Bezacier, L., Reynard, B., Bass, J.D., Sanchez-Valle, C., Van de Moortèle, B., 2010. Elasticity of antigorite, seismic detection of serpentinites, and anisotropy in subduction zones. Earth Planet. Sci. Lett. 289, 198-208.

Bloomer, S.H., Taylor, B., MacLeod, C.J., Stern, R.J., Fryer, P., Hawkins, J.W., Johnson, L., 1995, Early arc volcanism and the ophiolite problem. A perspective from drilling in the Western Pacific. In: Taylor, B., Natland, J., (Eds.), Active margin and marginal basins of the Western Pacific, AGU Geophysical Monograph, vol. 88, pp. 1-30.

Bostock, M.G., Hyndman, R.D., Rondenay, S., Peacock, S.M., 2002. An inverted continental Moho and serpentinization of the forearc mantle. Nature 417, 536-538.

Boudier, F., Baronnet, A., Mainprice, D., 2010. Serpentine mineral replacements of natural olivine and their seismic implications: Oceanic lizardite versus subduction-related antigorite. J. Petrol. 51, 495-512.

Bromiley, G.D., Pawley, A.R., 2003. The stability of antigorite in the systems $\mathrm{MgO}-\mathrm{SiO}_{2}-$ $\mathrm{H}_{2} \mathrm{O}(\mathrm{MSH})$ and $\mathrm{MgO}-\mathrm{Al}_{2} \mathrm{O}_{3}-\mathrm{SiO}_{2}-\mathrm{H}_{2} \mathrm{O}(\mathrm{MASH})$ : The effects of $\mathrm{Al}^{3+}$ substitution on high-pressure stability. Am. Mineral. 88, 99-108.

Bucher, K., Frey, M., 2002. Petrogenesis of metamorphic rocks. Springer-Verlag. 341 pp.

Cassidy, J.F., Bostock, M.G., 1996, Shear-wave splitting above the subducting Juan de Fuca plate. Geophys. Res. Lett. 23, 941-944.

Christensen, N.I., 1984. The magnitude, symmetry and origin of upper mantle anisotropy based on fabric analyses of ultramafic tectonites. Geophys. J. R. Astron. Soc. 76, 89-111. 
533

Currie, C.A., Cassidy, J.F., Hyndman, R.D., 2001. A regional study of shear wave splitting above the Cascadia Subduction Zone: Margin-parallel crustal stress. Geophys. Res. Lett. 28, 659-662.

DeShon, H.R., Schwartz, S.Y., 2004. Evidence for serpentinization of the forearc mantle wedge along the Nicoya Peninsula, Costa Rica. Geophys. Res. Lett. 31, L21611.

Dungan, M.A., 1979. A microprobe study of antigorite and some serpentine pseudomorphs. Can. Mineral. 17, 771-784.

Evans, B.W., 2004. The serpentinite multisystem revisited: Chrysotile is metastable. Int. Geol. Rev. 46, 479-506.

Gerya, T.V., Stöckhert, B., Perchuk, A.L., 2002. Exhumation of high-pressure metamorphic rocks in a subduction channel: A numerical simulation. Tectonics 21, 1056.

Hall, C.E., Fischer, K.M., Parmentier, E.M., Blackman, D.K., 2000. The influence of plate motions on three-dimensional back arc mantle flow and shear wave splitting. J. Geophys. Res. 105, 28009-28033.

Hilairet, N., Reynard, B., 2009. Stability and dynamics of serpentinite layer in subduction zone. Tectonophysics 465, 24-29.

Hilairet, N., Reynard, B., Wang, Y., Daniel, I., Merkel, S., Nishiyama, N., Petitgirard, S., 2007. High-pressure creep of serpentine, interseismic deformation, and initiation of subduction. Science 318, 1910-1913.

Hirauchi, K., 2006. Serpentinite textural evolution related to tectonically controlled solid-state intrusion along the Kurosegawa Belt, northwestern Kanto Mountains, central Japan. Island Arc 15, 156-164.

Hoernle, K., Abt, D.L., Fischer, K.M., Nichols, H., Hauff, F., Abers, G.A., van den Bogaard, P., Heydolph, K., Alvarado, G., Protti, M., Strauch, W., 2008. Arc-parallel flow in the mantle wedge beneath Costa Rica and Nicaragua. Nature 451, 1094-1097.

Holtzman, B.K., Kohlstedt, D.L., Zimmerman, M.E., Heidelbach, F., Hiraga, T., Hustoft, J., 2003. Melt segregation and strain partitioning: Implications for seismic anisotropy and mantle flow. Science 301, 1227-1230.

Hyndman, R.D., Peacock, S.M., 2003. Serpentinization of the forearc mantle. Earth Planet. Sci. Lett. 212, 417-432.

Jekins, D.M., 1983. Stability and composition relations of calcic amphiboles in ultramafic rocks. Contrib. Mineral. Petrol. 83, 375-384. 
Jung, H., Karato, S., 2001. Water-induced fabric transitions in olivine. Science 293, 14601463.

Jung, H., Katayama, I., Jiang, Z., Hiraga, T., Karato, S., 2006. Effect of water and stress on the lattice-preferred orientation of olivine. Tectonophysics 421, 1-22.

Jung, H., Mo, W., Green, H.W., 2009. Upper mantle seismic anisotropy resulting from pressure-induced slip transition in olivine. Nature Geoscience 2, 73-77.

Kamiya, S., Kobayashi, Y., 2000. Seismological evidence for the existence of serpentinized mantle. Geophys. Res. Lett. 27, 819-822.

Karig, D., 1971. Structural history of the Mariana island arc system. Geol. Soc. Am. Bull. 82, 323-344.

Katayama, I., 2009. Thin anisotropic layer in the mantle wedge beneath northeast Japan. Geology 37, 211-214.

Katayama, I., Hirauchi, K., Michibayashi, K., Ando, J., 2009. Trench-parallel anisotropy produced by serpentine deformation in the hydrated mantle wedge. Nature 461, 1114 1117.

Katayama, I., Karato, S., 2006. Effect of temperature on the B- to C-type olivine fabric transition and implication for flow pattern in subduction zones. Phys. Earth Planet. Inter. $157,33-45$.

Katayama, I., Karato, S., 2008. Low-temperature, high-stress deformation of olivine under water-saturated conditions. Phys. Earth Planet. Inter. 168, 125-133.

Kern, H., Liu, B., Popp, T., 1997. Relationship between anisotropy of P and S wave velocities and anisotropy of attenuation in serpentinite and amphibolite. J. Geophys. Res. 102, 30513065 .

Kincaid, C., Griffiths, R.W., 2003. Laboratory models of the thermal evolution of the mantle during rollback subduction. Nature 425, 58-62.

Kneller, E.A., Long, M.D., van Keken, P.E., 2008. Olivine fabric transitions and shear wave anisotropy in the Ryukyu subduction system. Earth Planet. Sci. Lett. 268, 268-282.

Kneller, E.A., van Keken, P.E., 2007. Trench-parallel flow and seismic anisotropy in the Mariana and Andean subduction systems. Nature 450, 1222-1225.

Kneller, E.A., van Keken, P.E., Karato, S., Park, J., 2005. B-type olivine fabric in the mantle wedge: Insights from high-resolution non-Newtonian subduction zone models. Earth Planet. Sci. Lett. 237, 781-797. 
Kneller, E.A., van Keken, P.E., Katayama, I., Karato, S., 2007. Stress, strain, and B-type olivine fabric in the fore-arc mantle: Sensitivity tests using high-resolution steady-state subduction zone models. J. Geophys. Res. 112, B04406.

Komabayashi, T., Hirose K., Funakoshi, K., Takafuji, N., 2005. Stability of phase A in antigorite (serpentine) composition determined by in situ X-ray pressure observations. Phys. Earth Planet. Inter. 151, 276-289.

Lassak, T.M., Fouch, M.J., Hall, C.E., Kaminski, É., 2006. Seismic characterization of mantle flow in subduction systems: Can we resolve a hydrated mantle wedge? Earth Planet. Sci. Lett. 243, 632-649.

Long, M.D., Silver, P.G., 2008. The subduction zone flow field from seismic anisotropy: A global view. Science 319, 315-318.

Long, M.D., Silver, P.G., 2009. Shear wave splitting and mantle anisotropy: Measurements, interpretations, and new directions. Surv. Geophys. 30, 407-461.

Long, M.D., van der Hilst, R.D., 2006. Shear wave splitting from local events beneath the Ryukyu arc: Trench-parallel anisotropy in the mantle wedge. Earth Planet. Sci. Lett. 155, 300-312.

Mainprice, D., Barruol, G., Ben IsmaÏl, W., 2000. The anisotropy of the Earth's mantle: from single crystal to polycrystal. In: Karato, S., Forte, A.M., Liebermann, R.C., Masters, G., Stixrude, L., (Eds.), Mineral physics and seismic tomography: From atomic to global, vol. 117, AGU Geophysical Monograph, pp. 237-264.

Mainprice, D., Humbert, M., 1994. Methods of calculating petrophysical properties from lattice preferred orientation data. Surv. Geophys. 15, 575-592.

Mainprice, D., Ildefonse, B., 2009. Seismic anisotropy of subduction zone mineralscontribution of hydrous phases. In: Lallemand, S., Funiciello, F., (Eds.), Subduction zone geodynamics, Frontiers in Earth Sciences, Springer-Verlag Berlin Heidelberg, pp. 63-84.

Mainprice, D., Silver, P.G., 1993. Interpretation of SKS-waves using samples from the subcontinental lithosphere. Phys. Earth Planet. Inter. 78, 257-280.

Maltman, A.J., 1978. Serpentinite textures in Anglesey, North Wales, United Kingdom. Geol. Soc. Am. Bull. 89, 972-980.

Matsubara, M., Obara, K., Kasahara, K., 2008. Three-dimensional P- and S-wave velocity structures beneath the Japan Islands obtained by high-density seismic stations by seismic tomography. Tectonophysics 454, 86-103. 
Mehl, L., Hacker, B.R., Hirth, G., Kelemen, P.B., 2003. Arc-parallel flow within the mantle wedge: Evidence from the accreted Talkeetna arc, south central Alaska. J. Geophys. Res. $108,23-75$.

Mellini, M., Rumori, C., Viti, C., 2005. Hydrothermally reset magmatic spinels in retrograde serpentinites: formation of "ferritchromit" rims and chlorite aureoles. Contrib. Mineral. Petrol. 149, 266-275.

Michibayashi, K., Ina, T., Kanagawa, K., 2006. The effect of dynamic recrystallization on olivine fabric and seismic anisotropy: Insight from a ductile shear zone, Oman ophiolite. Earth Planet. Sci. Lett. 244, 695-708.

Michibayashi, K., Mainprice, D., 2004. The role of pre-existing mechanical anisotropy on shear zone development within oceanic mantle lithosphere: an example from the Oman ophiolite. J. Petrol. 45, 405-414.

Michibayashi, K., Ohara, Y., Stern, R.J., Fryer, P., Kimura, J.-I., Tasaka, M., Harigane, Y., Ishii, T., 2009. Peridotites from a ductile shear zone within back-arc lithospheric mantle, southern Mariana Trench: Results of a Shinkai 6500 dive. Geochem. Geophys. Geosyst. 10, Q05X06.

Mizukami, T., Wallis, S.R., Yamamoto, J., 2004. Natural examples of olivine lattice preferred orientation patterns with a flow-normal a-axis maximum. Nature 427, 432-436.

Nakajima, J., Hasegawa, A., 2004. Shear-wave polarization anisotropy and subductioninduced flow in the mantle wedge of northeastern Japan. Earth Planet. Sci. Lett. 225, 365377.

Niida, K., Green, D.H., 1999. Stability and chemical composition of pargasitic amphibole in MORB pyrolite under upper mantle conditions. Contrib. Mineral. Petrol. 135, 18-40.

Niida, K., Izumino, T., Yuasa, M., 2003. The Ohmachi seamount serpentinites derived from the uppermost mantle beneath oceanic island-arc. Chikyu Monthly 43, 90-100 (in Japanese).

Niida, K., Yuasa, M., Nishimura, A., Fujiwara, T., Watanabe, T., 2001. Serpentinites from Ohmachi Seamount: Origin of basement lithosphere of the Izu-Ogasawara Arc. JAMSTEC Journal of Deep Sea Research 19, 77-86 (in Japanese with English abstract).

Nishimura, A., 1992. Carbonate bioclasts of shallow-water origin at Site 793. In: Taylor, B., Fujioka, K., et al., (Eds.), Proceedings of the Ocean Drilling Program, Scientific Results, vol. 126, College Station, Texas, Ocean Drilling Program, pp. 231-234. 
661

662

663

664

665

666

667

668

669

670

671

672

673

674

675

676

677

678

679

680

681

682

683

684

685

686

687

688

689

690

691

Nozaka, T., 2005. Metamorphic history of serpentinite mylonites from the Happo ultramafic complex, central Japan. J. metamorphic Geol. 23, 711-723.

Ohara, Y., Ishii, T., 1998. Peridotites from the southern Mariana forearc: Heterogeneous fluid supply in mantle wedge. Island Arc 7, 541-558.

Pera, E., Mainprice, D., Burlinic, L., 2003. Anisotropic seismic properties of the upper mantle beneath the Torre Alfina area (Northern Apennines, Central Italy). Tectonophysics 370, $11-30$.

Pozgay, S.H., Wiens, D.A., Conder, J.A., Shiobara, H., Sugioka, H., 2007. Complex mantle flow in the Mariana subduction system: evidence from shear wave splitting. Geophys. J. Int. 170, 371-386.

Rinaudo, C., Gastaldi, D., Belluso, E., 2003. Characterization of chrysotile, antigorite and lizardite by FT-Raman spectroscopy. Can. Mineral. 41, 883-890.

Salah, M.K., Seno, T., Iidaka, T., 2008. Upper mantle anisotropy beneath central and southwest Japan: An insight into subduction-induced mantle flow. J. Geodynamics 46, 21-37.

Savage, M.K., 1999, Seismic anisotropy and mantle deformation: What have we learned from shear wave splitting? Rev. Geophys. 37, 65-106.

Schmidt, M.W., Poli, S., 1998. Experimentally based water budgets for dehydrating slabs and consequences for arc magma generation. Earth Planet. Sci. Lett. 163, 361-379.

Skemer, P., Katayama, I., Jiang, Z., Karato, S., 2005. The misorientation index: Development of a new method for calculating the strength of lattice-preferred orientation. Tectonophysics 411, 157-167.

Smith, G.P., Wiens, D.A., Fischer, K.M., Dorman, L.M., Webb, S.C., Hildebrand, J.A., 2001. A complex pattern of mantle flow in the Lau backarc. Science 292, 713-716.

Soda, Y., Takagi, H., in press. Sequential deformation from serpentinite mylonite to metasomatic rocks along the Sashu Fault, SW Japan. J. Struct. Geol.

Stern, R.J., Bloomer, S.H., 1992. Subduction Zone Infancy; Examples from the Eocene IzuBonin-Mariana and Jurassic California Arcs. Geol. Soc. Am. Bull. 104, 1621-1636.

Stern, R.J., Fouch, M.J., Klemperer, S.L., 2003. An overview of the Izu-Bonin-Mariana subduction factory. In: Eiler, J. (Ed.), Inside the subduction factory, vol. 138, AGU Geophysical Monograph, pp. 175-222. 
692

693

694

695

696

697

698

699

700

701

702

703

704

705

706

707

708

709

710

711

712

713

714

715

716

717

718

719

720

721

722

723

724

Tasaka, M., Michibayashi, K., Mainprice, D., 2008. B-type olivine fabrics developed in the fore-arc side of the mantle wedge along a subducting slab. Earth Planet. Sci. Lett. 272, 747-757.

Ueda, H., Usuki, T., Hirauchi, K., Meschede, M., Niida, K., 2009. Serpentinite-eclogite complex in the Ohmachi Seamount, Izu-Bonin arc: a fossil subduction channel in the Philippine Sea plate. Eos Trans. AGU 90, Fall Meet. Suppl., Abstract T32A-08.

Ueda, H., Usuki, T., Kuramoto, Y., 2004. Intraoceanic unroofing of eclogite facies rocks in the Omachi Seamount, Izu-Bonin frontal arc. Geology 32, 849-852.

Ulmer, P., Trommsdorff, V., 1995. Serpentine stability to mantle depths and subductionrelated magmatism. Science 268, 858-861.

Wada, I., Wang, K., He, J., Hyndman, R.D., 2008. Weakening of the subduction interface and its effects on surface heat flow, slab dehydration, and mantle wedge serpentinization. J. Geophys. Res. 113, B04402.

Wallace, M.E., Green, D.H., 1991. The effect of bulk rock composition on the stability of amphibole in the upper mantle: implications for solidus positions and mantle metasomatism. Mineral. Petrol. 44, 1-19.

Watanabe, T., Kasami, H., Ohshima, S., 2007. Compressional and shear wave velocities of serpentinized peridotites up to $200 \mathrm{MPa}$. Earth Planets Space 59, 233-244.

Wicks, F.J., Whittaker, E.J.W., 1977. Serpentine textures and serpentinization. Can. Mineral. $15,459-488$.

Wiens, D.A., Conder, J.A., Faul, U.H., 2008. The seismic structure and dynamics of the mantle wedge. Annu. Rev. Earth Planet. Sci., 36, 421-455.

Yuasa, M., Nishimura, A., Niida, K., Ishizuka, O., 1998. A serpentine diapir forming part of the Ohmachi Seamount near the volcanic front of the Izu-Ogasawara Arc (Shinkai 6500 \#341). JAMSTEC Journal of Deep Sea Research 14, 269-277 (in Japanese with English abstract).

Yuasa, M., Nishimura, A., Niida, K., Ishizuka, O., 1999. Tertiary system adjacent to the volcanic front of the central Izu-Bonin arc: Geology of the Ohmachi Seamount. Chikyu Monthly 23, 107-115 (in Japanese).

Zhang, S., Karato, S., 1995. Lattice preferred orientation of olivine aggregates deformed in simple shear. Nature 375, 774-777.

Zhang, S., Karato, S., Fitz Gerald, J., Faul, U.H., Zhou, Y., 2000. Simple shear deformation of olivine aggregates. Tectonophysics $316,133-152$. 


\section{Captions}

726 Figure 1. (A) Bathymetric map of the Izu-Bonin-Mariana arc-back-arc region. Contour interval is $1000 \mathrm{~m}$. (B) Seafloor topography and inferred geology around the Ohmachi Seamount (1: Quaternary volcanic rocks, 2: basin-fill deposits, 3: Neogene sedimentary rocks, 4: Paleogene volcanic rocks, 5: serpentinite, 6: fault scarp). Contour interval is $500 \mathrm{~m}$. Modified from Ueda et al. (2004).

Figure 2. (A) Bathymetric map showing the dive track (dark line) of the Shinkai 6500 (dive 6k\#1066) and sampling locations (S1-S7). Contour interval is $20 \mathrm{~m}$. (B) Sampling depth versus rock type of recovered samples. Solid and open symbols represent samples collected from outcrop and as float, respectively. atg: antigorite, ctl: chrysotile, liz: lizardite.

Figure 3. Optical photomicrographs of serpentinite samples (cross-polarized light). (A) Olivine (ol) crystal with conspicuous cleavage. Note that cleavage planes are infilled with antigorite film. (B) Typical interpenetrating texture, characterized by randomly oriented antigorite (atg) blades. (C) Schistose antigorite (atg) blades with lens-shaped relics of interpenetrating blades. IPT: interpenetrating texture. (D) Relict olivine (ol) grain surrounded by schistose antigorite (atg) blades. Note the occurrence of lizardite (liz) crystals as mesh rim within the olivine grain. (E) Elongate porphyroclast of bastite (BS) aligned parallel to the antigorite (atg) schistosity. (F) Acicular diopside (di) grains aligned parallel to the antigorite (atg) schistosity. (G) Schistose antigorite (atg) blades along with magnetite (mgt) ribbons overprinted by open microfolds, the limbs of which contain a weak crenulation cleavage. sp: spinel. (H) Interpenetrating antigorite (atg) blades that appear to be partially replaced by chlorite (chl). cal: calcite. (I) Altered (serpentinized) olivine grain within schistose antigorite (atg) blades. Note the occurrence of homogeneous mesh texture within the altered grain, comprising polyhedral cores (cr) surrounded by fibrous rims.

749 Figure 4. Compositional trends obtained for serpentine within serpentinite from the Ohmachi

750 Seamount. (A) Si vs. Al. (B) Cr vs. Al. Cations are calculated based on seven oxygens. atg: 751 antigorite, liz: lizardite.

752 Figure 5. Compositional trends obtained for serpentine and chlorite within serpentinite from the Ohmachi Seamount, plotted in a Mg-Al-Si ternary diagram (symbols as in Fig. 4).

754 Figure 6. Optical photomicrographs of three selected samples of antigorite serpentinites from 755 the Ohmachi Seamount (cross-polarized light). Scale bars are all $1 \mathrm{~mm}$. The 
photomicrographs in (B, D, F) were taken with the gypsum plate inserted. (A and B) Massive type (sample \#1065R006). (C and D) Transitional type (sample \#1064R012). (E and F) Schistose type (sample \#1066R013).

759 Figure 7. Pole figures showing the orientations of the crystallographic axes of antigorite 760 grains. (A) Massive type (sample \#1065R006). (B) Transitional type (sample \#1064R012). 761 (C) Schistose type (sample \#1066R013). Equal-area, lower-hemisphere projections. Contours 762 are in multiples of uniform distribution (m.u.d.). In the case that structural features could be 763 observed in the analyzed samples (i.e., B and C), foliation is oriented vertical in the figure 764 (XY plane; solid line) and lineation (X) is horizontal within the plane of the foliation. $J, M$, 765 and $p f j$ are the fabric intensities calculated after Ben Ismaïl and Mainprice (1998), 766 Michibayashi and Mainprice (2004), and Skemer et al. (2005), respectively.

767 Figure 8. Seismic properties calculated from the CPOs of antigorite within the analyzed 768 samples. (A) Massive type (sample \#1065R006). (B) Transitional type (sample \#1064R012). 769 (C) Schistose type (sample \#1066R013). Equal-area, lower-hemisphere projections. Contours 770 are in multiples of uniform distribution (m.u.d.). Contours for $V p$ (left-hand column) are in $771 \mathrm{~km} / \mathrm{s}$, while those for $A V \mathrm{~s}$ (middle column) are in \% anisotropy. In the right-hand column, the short lines represent the trace of the $V \mathrm{~s}_{1}$ polarization plane. In the case that structural features could be observed in the analyzed samples (i.e., B and C), foliation is oriented vertical in the

774 figure (XY plane; solid line) and lineation (X) is horizontal within the plane of the foliation.

775 Figure 9. Relationship between seismic anisotropy ( $A V \mathrm{p}$ and $A V \mathrm{~s}$ ) and fabric strength $(M$ 776 index) for aggregates of antigorite in natural samples (present study; black symbols) and in 777 experimentally deformed samples (Katayama et al., 2009; gray symbols). SM: starting 778 material, M: massive type, T: transitional type, S: schistose type. Numbers next to data points 779 indicate the magnitude of shear strain $(\gamma)$ during deformation. 


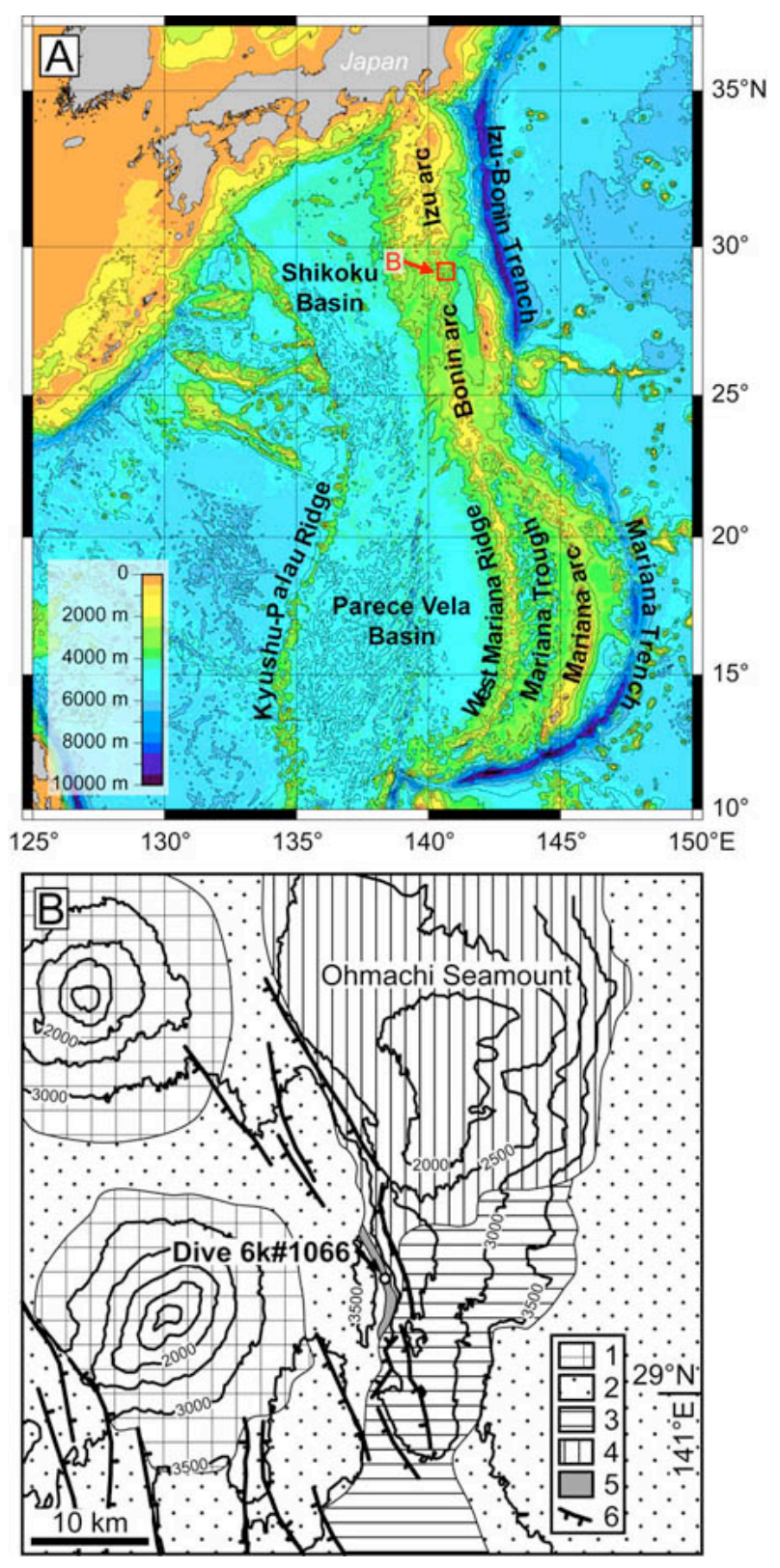

Figure 1 

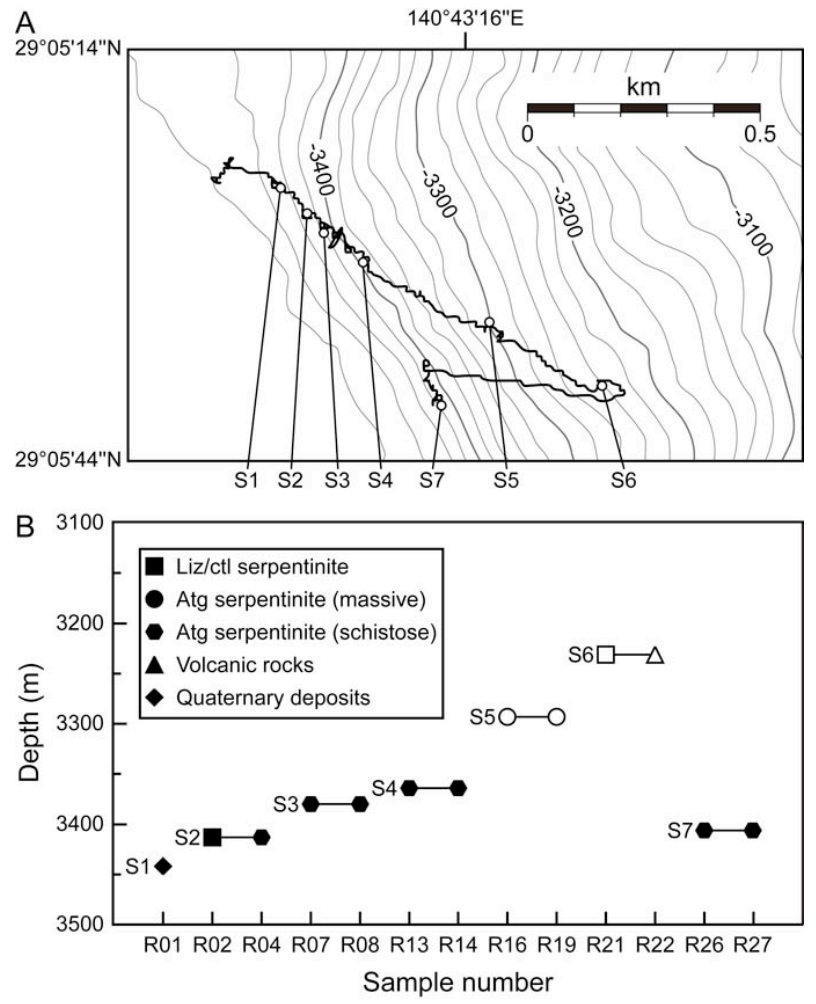

Figure 2 

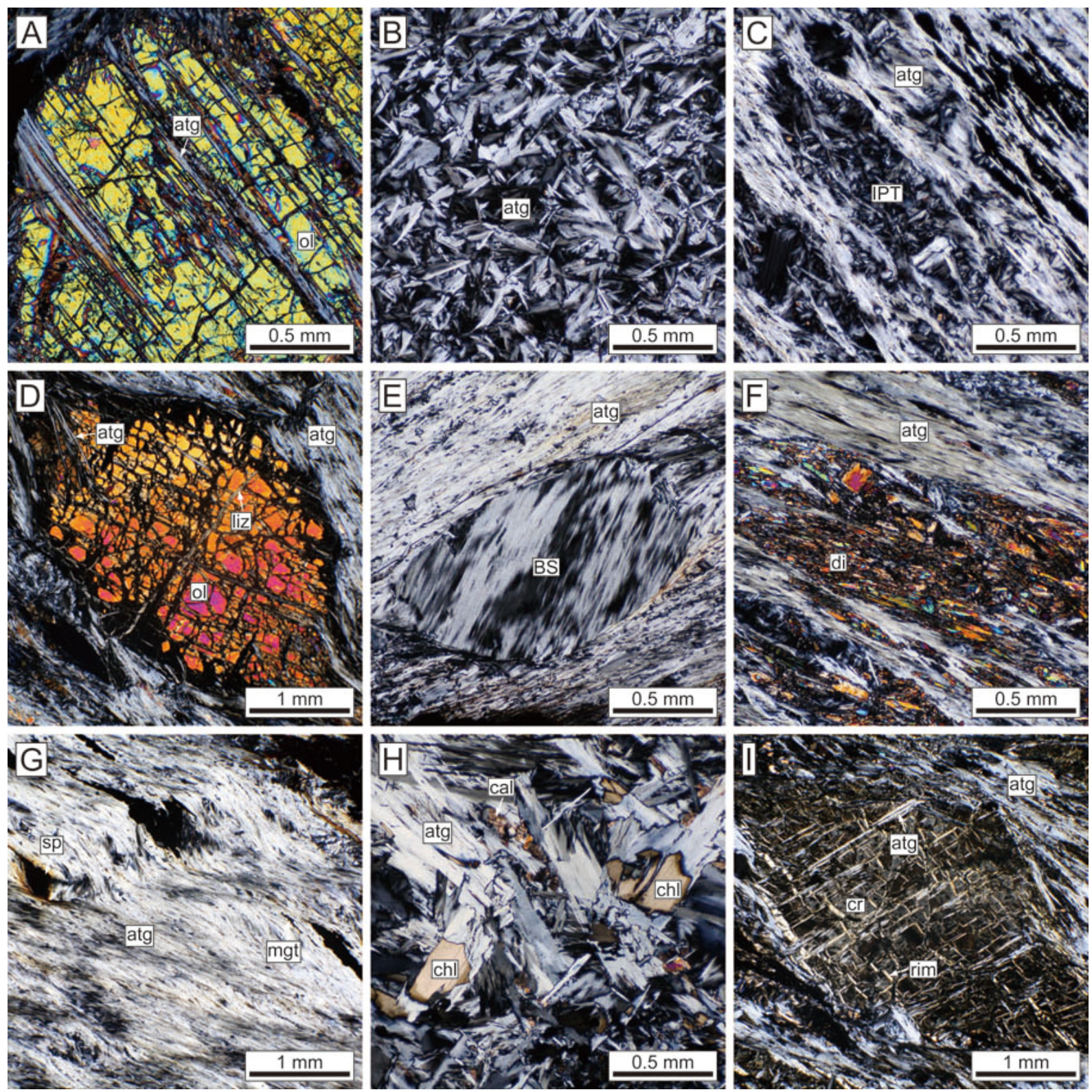

Figure 3 

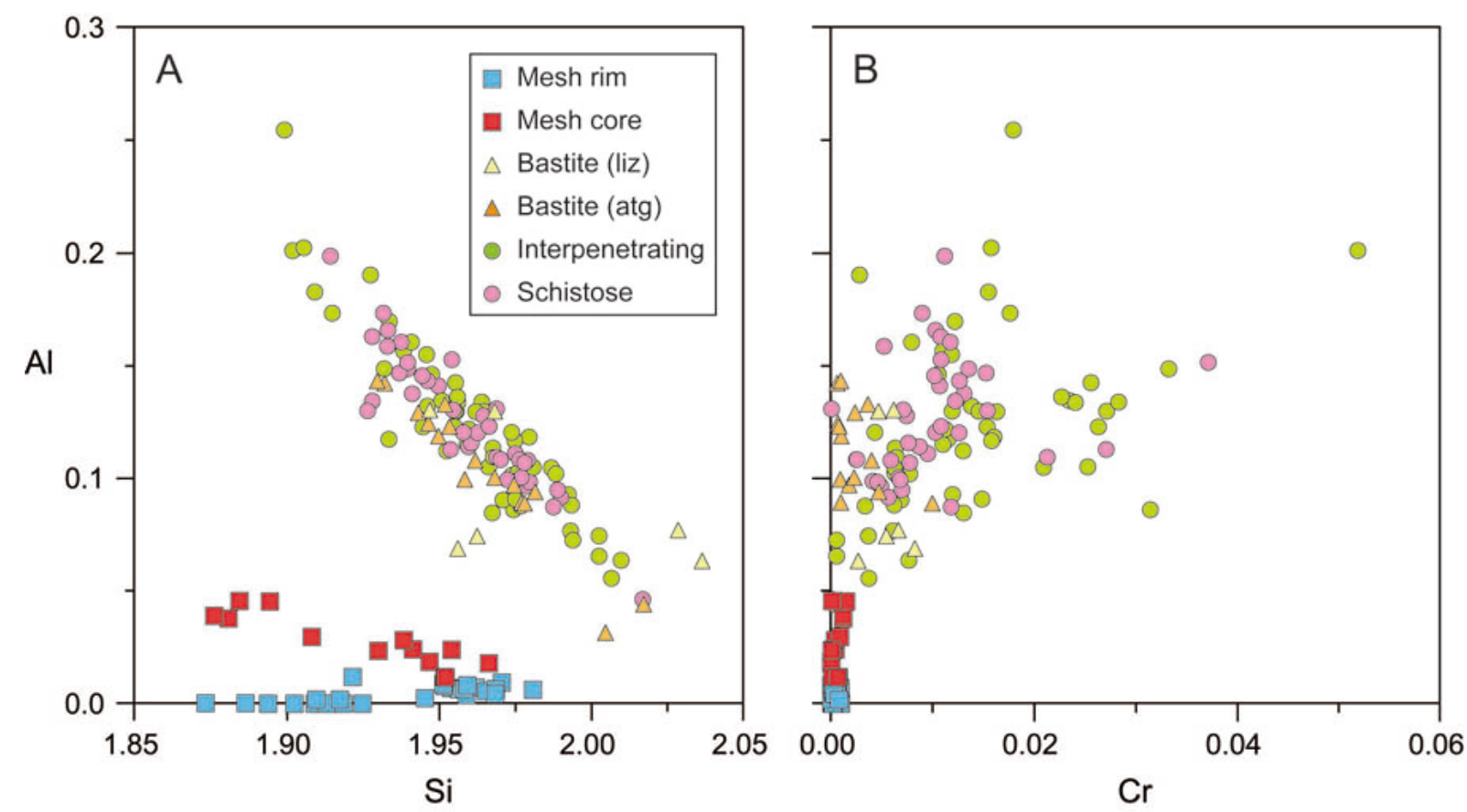

Figure 4 


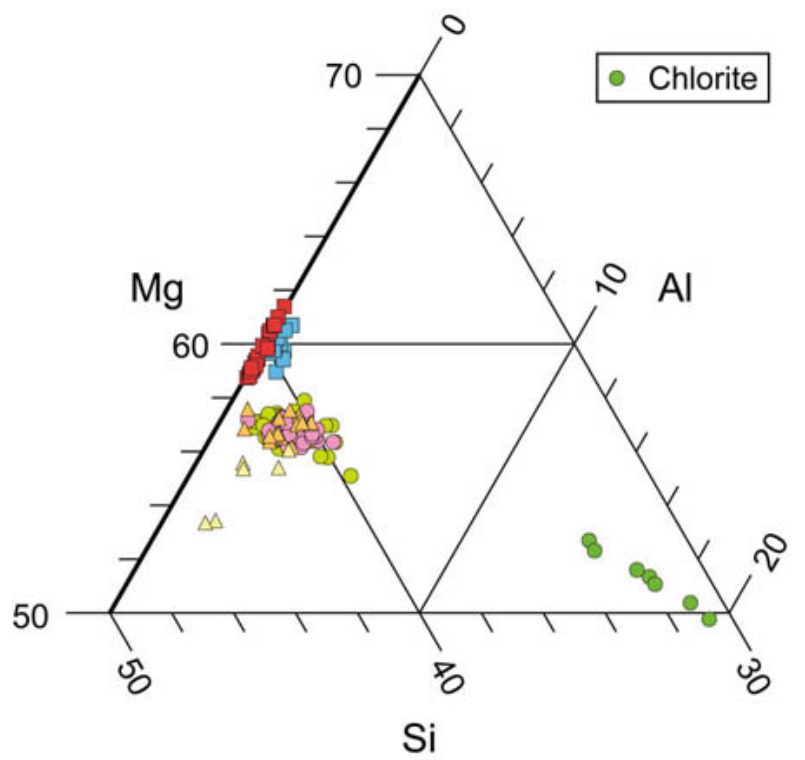

Figure 5 


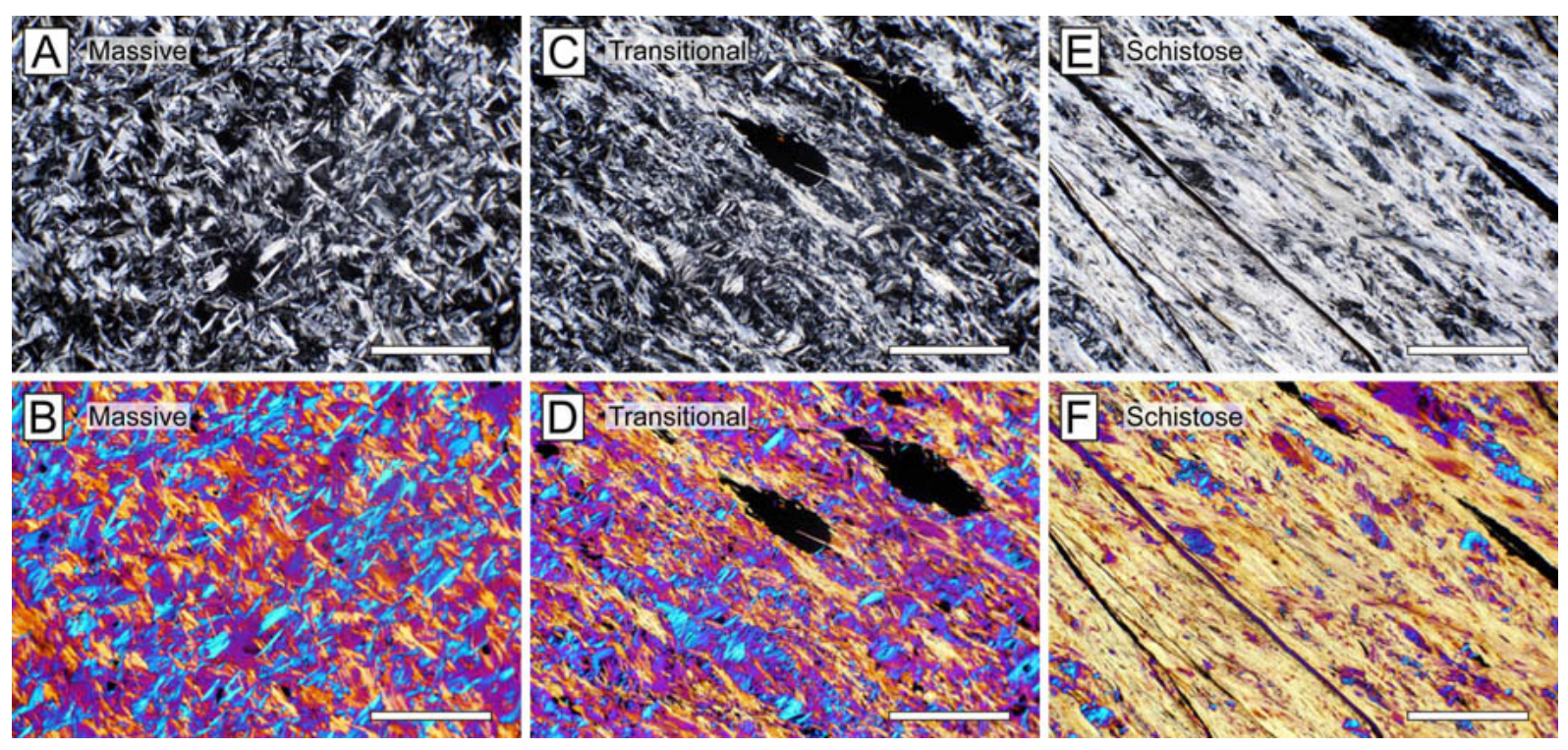

Figure 6 
(100)
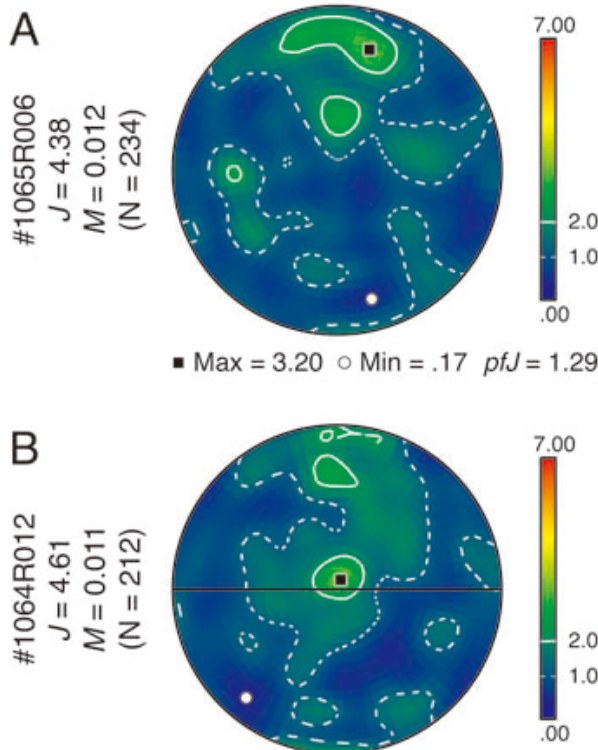

- $\operatorname{Max}=3.42 \circ \operatorname{Min}=.08 p f J=1.27$

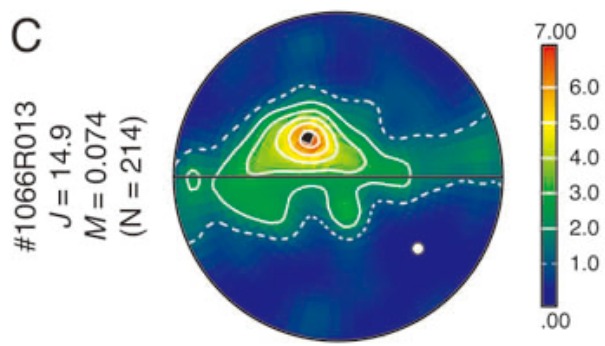

- $\operatorname{Max}=6.57 \circ \operatorname{Min}=.00 p f J=2.29$
(010)

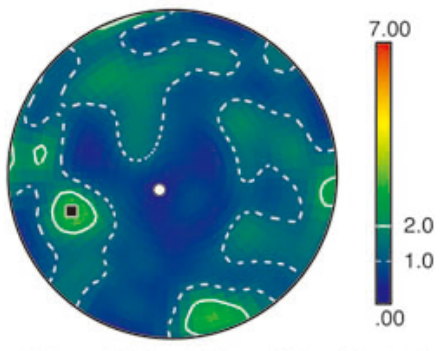

- $\operatorname{Max}=3.23 \circ \mathrm{Min}=.09 \mathrm{pfJ}=1.29$

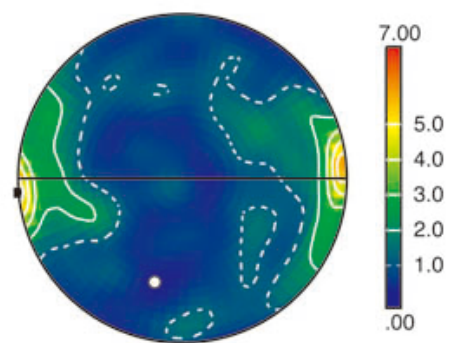

- $\operatorname{Max}=5.64 \circ \operatorname{Min}=.04 p f J=1.63$

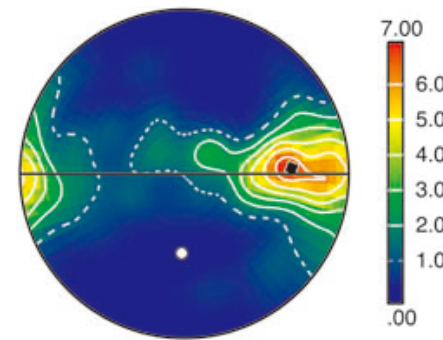

- $\operatorname{Max}=6.89 \circ \mathrm{Min}=.00 \mathrm{pfJ}=2.99$

Figure 7

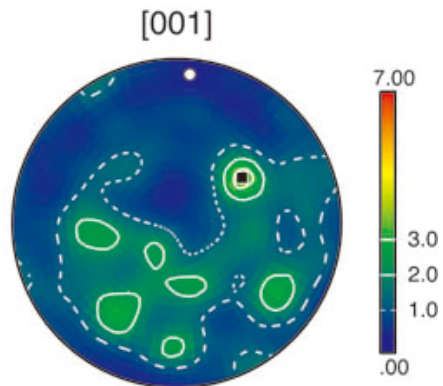

- $\operatorname{Max}=3.60 \circ \operatorname{Min}=.05 p f J=1.39$

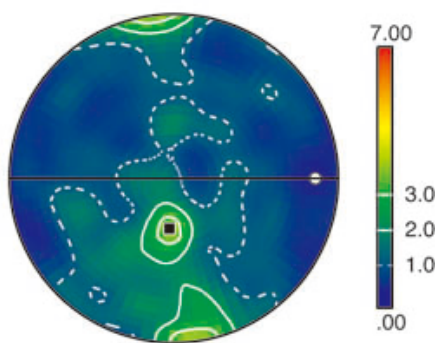

- $\operatorname{Max}=3.66 \circ \mathrm{Min}=.04 \mathrm{pfJ}=1.40$

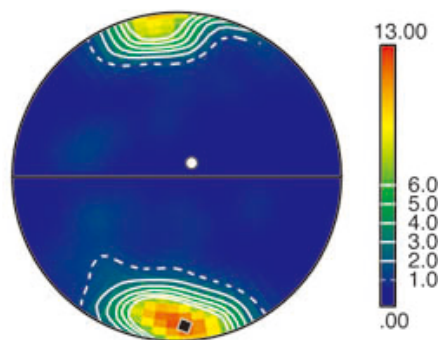

- $\operatorname{Max}=12.25 \circ \mathrm{Min}=.00 \mathrm{pfJ}=5.59$ 

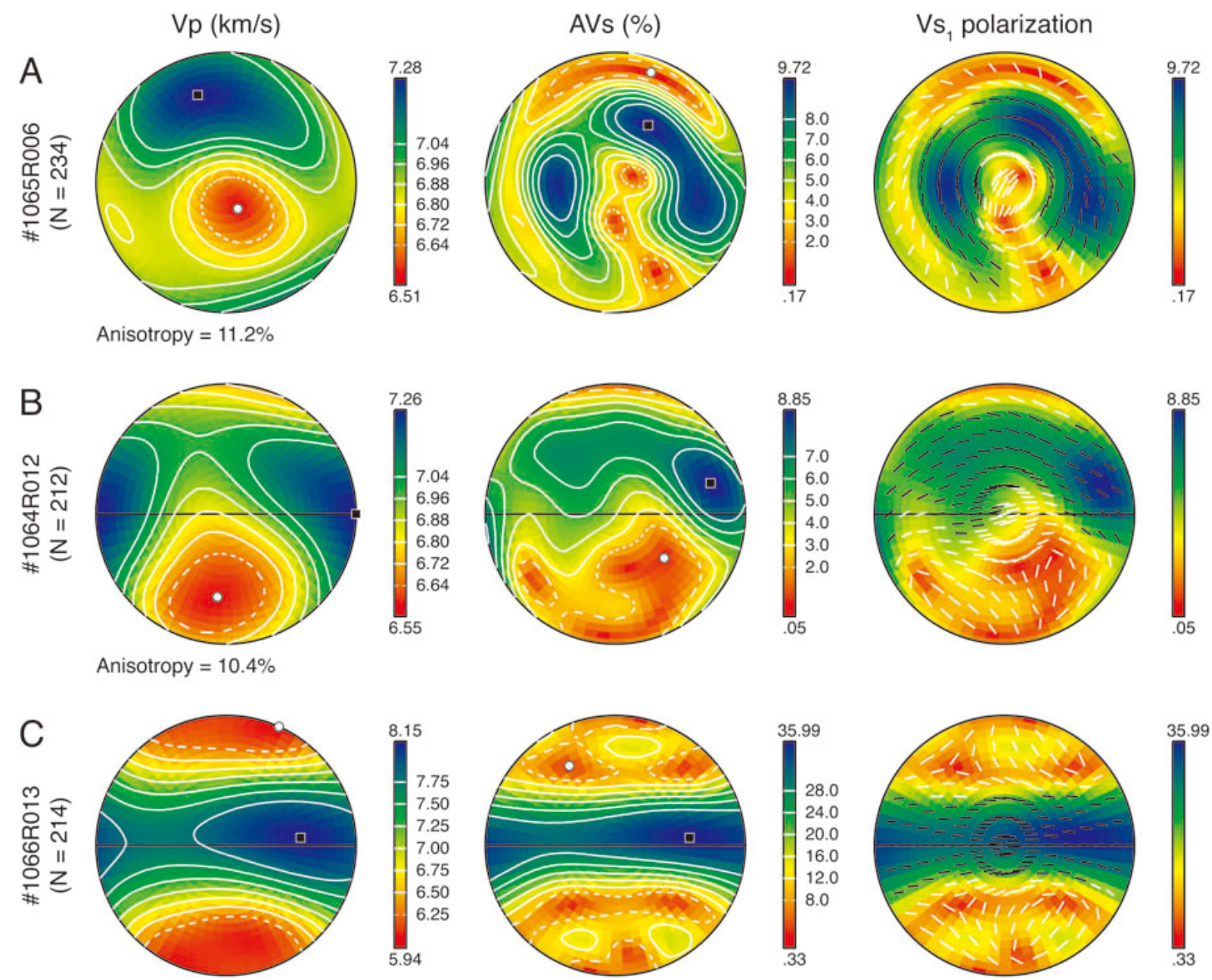

Anisotropy $=31.3 \%$

Figure 8 


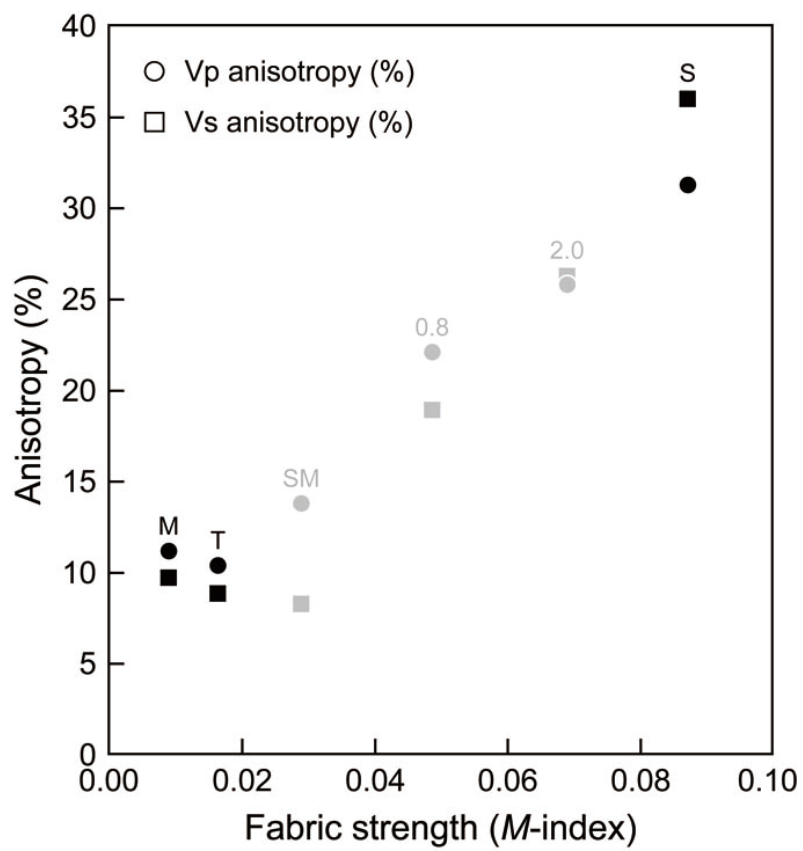

Figure 9 


\begin{tabular}{|c|c|c|c|c|c|c|c|c|c|c|c|c|c|c|c|c|c|c|c|c|c|c|}
\hline \multirow{3}{*}{$\begin{array}{c}\text { Sample no: } \\
\text { Rock type } \\
\text { Mineral }\end{array}$} & \multirow{2}{*}{\multicolumn{2}{|c|}{$\frac{\# 1064 \mathrm{R} 002}{\text { clinopyroxenite }}$}} & \multirow{3}{*}{$\begin{array}{c}\# 1065 \mathrm{R} 006 \\
\begin{array}{c}\text { antigorite } \\
\text { serpentinite }\end{array} \\
\text { atg_I }\end{array}$} & \multirow{2}{*}{\multicolumn{2}{|c|}{$\frac{\# 1066 \mathrm{R} 008}{\text { antigorite schist }}$}} & \multirow{3}{*}{$\begin{array}{c}\# 1066 \mathrm{R} 013 \\
\begin{array}{c}\text { antigorite } \\
\text { schist }\end{array} \\
\text { Cr-mgt }\end{array}$} & \multirow{2}{*}{\multicolumn{3}{|c|}{$\begin{array}{c}\text { \#1066R021 } \\
\text { lherzolite }\end{array}$}} & \multirow{2}{*}{\multicolumn{2}{|c|}{$\frac{\# 1066 \mathrm{R} 025}{\text { antigorite schist }}$}} & \multirow{2}{*}{\multicolumn{3}{|c|}{$\frac{\# 1068 \mathrm{R} 001}{\text { antigorite schist }}$}} & \multirow{2}{*}{\multicolumn{2}{|c|}{$\frac{\# 1068 \mathrm{R} 004}{\text { antigorite schist }}$}} & \multirow{2}{*}{\multicolumn{2}{|c|}{$\frac{\# 1068 \mathrm{R} 007}{\text { antigorite schist }}$}} & \multirow{2}{*}{\multicolumn{4}{|c|}{$\frac{\# 1068 \mathrm{R} 015}{\text { wehrlite }}$}} \\
\hline & & & & & & & & & & & & & & & & & & & & & & \\
\hline & P-cpx & $\operatorname{atg} \_B$ & & atg_I & $\operatorname{atg} \_\mathrm{S}$ & & $\mathrm{sp}$ & liz_MR & liz_B & ol & M-cpx & atg_I & atg_S & chl_I & ol & M-cpx & liz_MR & ctl_MC & M-cpx & ed_core & tr_rim & $\operatorname{tr}$ \\
\hline $\mathrm{SiO}_{2}$ & 53.3 & 41.1 & 42.0 & 42.0 & 42.1 & 0.0 & 0.0 & 39.7 & 39.1 & 39.8 & 55.0 & 41.8 & 41.6 & 33.6 & 41.0 & 54.9 & 39.1 & 39.3 & 54.6 & 46.2 & 57.9 & 56.0 \\
\hline $\mathrm{TiO}_{2}$ & 0.09 & 0.00 & 0.00 & 0.01 & 0.02 & 0.69 & 0.10 & 0.02 & 0.05 & 0.00 & 0.04 & 0.02 & 0.01 & 0.01 & 0.01 & 0.02 & 0.02 & 0.01 & 0.00 & 0.81 & 0.01 & 0.06 \\
\hline $\mathrm{Al}_{2} \mathrm{O}_{3}$ & 1.55 & 2.24 & 1.58 & 2.22 & 1.75 & 0.02 & 46.8 & 0.12 & 1.26 & 0.00 & 0.05 & 2.83 & 2.76 & 12.5 & 0.02 & 0.02 & 0.03 & 0.41 & 0.07 & 10.65 & 0.24 & 1.19 \\
\hline $\mathrm{FeO}^{*}$ & 2.78 & 3.23 & 3.43 & 3.04 & 2.99 & 84.3 & 18.7 & 4.56 & 9.17 & 11.4 & 1.61 & 3.13 & 3.17 & 3.52 & 9.74 & 1.43 & 6.80 & 2.46 & 1.34 & 3.91 & 1.45 & 1.85 \\
\hline $\mathrm{MnO}$ & 0.13 & 0.07 & 0.09 & 0.09 & 0.05 & 0.40 & 0.19 & 0.04 & 0.07 & 0.32 & 0.01 & 0.05 & 0.05 & 0.03 & 0.18 & 0.04 & 0.14 & 0.03 & 0.01 & 0.08 & 0.06 & 0.04 \\
\hline $\mathrm{Cr}_{2} \mathrm{O}_{3}$ & 0.52 & 0.02 & 0.09 & 0.30 & 0.13 & 6.76 & 17.5 & 0.02 & 0.14 & 0.03 & 0.17 & 0.32 & 0.29 & 0.79 & 0.00 & 0.20 & 0.00 & 0.00 & 0.05 & 0.73 & 0.00 & 0.04 \\
\hline $\mathrm{MgO}$ & 17.2 & 39.5 & 39.4 & 39.6 & 39.5 & 0.9 & 16.7 & 39.2 & 34.0 & 48.3 & 17.5 & 39.3 & 38.8 & 35.6 & 49.9 & 17.8 & 39.3 & 40.9 & 17.9 & 18.6 & 23.6 & 23.2 \\
\hline $\mathrm{CaO}$ & 24.5 & 0.01 & 0.00 & 0.01 & 0.01 & 0.01 & 0.00 & 0.05 & 0.13 & 0.00 & 25.3 & 0.01 & 0.00 & 0.02 & 0.01 & 25.4 & 0.02 & 0.02 & 25.5 & 12.6 & 13.0 & 12.5 \\
\hline $\mathrm{Na}_{2} \mathrm{O}$ & 0.11 & 0.01 & 0.02 & 0.00 & 0.00 & 0.03 & 0.05 & 0.03 & 0.05 & 0.01 & 0.41 & 0.03 & 0.03 & 0.07 & 0.01 & 0.19 & 0.00 & 0.02 & 0.11 & 3.23 & 0.68 & 1.77 \\
\hline $\mathrm{K}_{2} \mathrm{O}$ & 0.00 & 0.00 & 0.01 & 0.00 & 0.01 & 0.00 & 0.01 & 0.00 & 0.02 & 0.00 & 0.00 & 0.01 & 0.00 & 0.03 & 0.00 & 0.00 & 0.01 & 0.02 & 0.00 & 0.38 & 0.03 & 0.11 \\
\hline $\mathrm{NiO}$ & 0.02 & 0.07 & 0.08 & 0.05 & 0.08 & 0.27 & 0.32 & 0.29 & 0.29 & 0.31 & 0.00 & 0.04 & 0.04 & 0.02 & 0.41 & 0.03 & 0.16 & 0.14 & 0.03 & 0.07 & 0.06 & 0.07 \\
\hline Total & 100.3 & 86.2 & 86.7 & 87.3 & 86.7 & 93.4 & 100.3 & 84.0 & 84.2 & 100.2 & 100.1 & 87.6 & 86.7 & 86.3 & 101.3 & 100.1 & 85.6 & 83.3 & 99.6 & 97.2 & 97.0 & 96.9 \\
\hline Cations & $O=6$ & $O=7$ & $O=7$ & $O=7$ & $O=7$ & $O=4$ & $O=4$ & $O=7$ & $O=7$ & $O=4$ & $O=6$ & $O=7$ & $O=7$ & $O=7$ & $O=4$ & $O=6$ & $O=7$ & $O=7$ & $O=6$ & $O=23$ & $O=23$ & $O=23$ \\
\hline $\mathrm{Si}$ & 1.94 & 1.95 & 1.98 & 1.96 & 1.98 & 0.00 & 0.00 & 1.95 & 1.96 & 0.98 & 2.00 & 1.95 & 1.95 & 1.61 & 0.99 & 1.99 & 1.92 & 1.93 & 1.99 & 6.58 & 7.96 & 7.77 \\
\hline $\mathrm{Ti}$ & 0.00 & 0.00 & 0.00 & 0.00 & 0.00 & 0.03 & 0.00 & 0.00 & 0.00 & 0.00 & 0.00 & 0.00 & 0.00 & 0.00 & 0.00 & 0.00 & 0.00 & 0.00 & 0.00 & 0.09 & 0.00 & 0.01 \\
\hline $\mathrm{Al}$ & 0.07 & 0.12 & 0.09 & 0.12 & 0.10 & 0.00 & 1.52 & 0.01 & 0.07 & 0.00 & 0.00 & 0.16 & 0.15 & 0.71 & 0.00 & 0.00 & 0.00 & 0.02 & 0.00 & 1.79 & 0.04 & 0.20 \\
\hline $\mathrm{Fe}^{2+}$ & 0.08 & 0.13 & 0.14 & 0.12 & 0.12 & 1.19 & 0.32 & 0.19 & 0.38 & 0.24 & 0.05 & 0.12 & 0.12 & 0.14 & 0.20 & 0.04 & 0.28 & 0.10 & 0.04 & 0.47 & 0.17 & 0.21 \\
\hline $\mathrm{Fe}^{3+}$ & & & & & & 2.24 & 0.11 & & & & & & & & & & & & & & & \\
\hline $\mathrm{Mn}$ & 0.00 & 0.00 & 0.00 & 0.00 & 0.00 & 0.02 & 0.00 & 0.00 & 0.00 & 0.01 & 0.00 & 0.00 & 0.00 & 0.00 & 0.00 & 0.00 & 0.01 & 0.00 & 0.00 & 0.01 & 0.01 & 0.00 \\
\hline $\mathrm{Cr}$ & 0.01 & 0.00 & 0.00 & 0.01 & 0.00 & 0.26 & 0.38 & 0.00 & 0.01 & 0.00 & 0.00 & 0.01 & 0.01 & 0.03 & 0.00 & 0.01 & 0.00 & 0.00 & 0.00 & 0.08 & 0.00 & 0.00 \\
\hline $\mathrm{Mg}$ & 0.93 & 2.78 & 2.77 & 2.76 & 2.77 & 0.07 & 0.69 & 2.87 & 2.54 & 1.78 & 0.94 & 2.73 & 2.72 & 2.54 & 1.80 & 0.96 & 2.87 & 2.99 & 0.97 & 3.96 & 4.83 & 4.81 \\
\hline $\mathrm{Ca}$ & 0.96 & 0.00 & 0.00 & 0.00 & 0.00 & 0.00 & 0.00 & 0.00 & 0.01 & 0.00 & 0.98 & 0.00 & 0.00 & 0.00 & 0.00 & 0.99 & 0.00 & 0.00 & 0.99 & 1.92 & 1.92 & 1.85 \\
\hline $\mathrm{Na}$ & 0.01 & 0.00 & 0.00 & 0.00 & 0.00 & 0.00 & 0.00 & 0.00 & 0.00 & 0.00 & 0.03 & 0.00 & 0.00 & 0.01 & 0.00 & 0.01 & 0.00 & 0.00 & 0.01 & 0.89 & 0.18 & 0.48 \\
\hline $\mathrm{K}$ & 0.00 & 0.00 & 0.00 & 0.00 & 0.00 & 0.00 & 0.00 & 0.00 & 0.00 & 0.00 & 0.00 & 0.00 & 0.00 & 0.00 & 0.00 & 0.00 & 0.00 & 0.00 & 0.00 & 0.07 & 0.01 & 0.02 \\
\hline $\mathrm{Ni}$ & 0.00 & 0.00 & 0.00 & 0.00 & 0.00 & 0.01 & 0.01 & 0.01 & 0.01 & 0.01 & 0.00 & 0.00 & 0.00 & 0.00 & 0.01 & 0.00 & 0.01 & 0.01 & 0.00 & 0.01 & 0.01 & 0.01 \\
\hline Total & 4.02 & 4.99 & 4.98 & 4.97 & 4.97 & 3.84 & 3.05 & 5.04 & 5.00 & 3.02 & 4.01 & 4.97 & 4.97 & 5.03 & 3.01 & 4.01 & 5.08 & 5.06 & 4.01 & 15.87 & 15.11 & 15.37 \\
\hline
\end{tabular}

*Total iron given as $\mathrm{FeO} ; \mathrm{Fe}^{2+}$ and $\mathrm{Fe}^{3+}$ of spinel and $\mathrm{Cr}$-magnetite were calculated assuming spinel stoichiometry.

B-bastite, I-interpenetrating, M-metamorphic, MC-mesh core, MR-mesh rim, P-primary, S-schistose. 
Supplementary Table 2. Seismic properties (Vp, Vs) of antigorite serpentinites from the Ohmachi Seamount

\begin{tabular}{|c|c|c|c|c|c|c|c|c|c|c|c|c|c|}
\hline & & \multirow[t]{3}{*}{ Sample no: } & \multicolumn{3}{|l|}{$\mathrm{Vp}$} & \multirow{2}{*}{$\begin{array}{c}\text { AVs } \\
\text { Max } \\
\end{array}$} & \multicolumn{3}{|l|}{$\mathrm{Vs}_{1}$} & \multicolumn{3}{|l|}{$\mathrm{Vs}_{2}$} & \multirow{3}{*}{$\frac{\mathrm{dVs}}{\mathrm{Max}}$} \\
\hline & & & Max & Min & Anisotropy & & Max & Min & Anisotropy & Max & Min & Anisotropy & \\
\hline & & & $(\mathrm{km} / \mathrm{s})$ & $(\mathrm{km} / \mathrm{s})$ & $(\%)$ & $(\%)$ & $(\mathrm{km} / \mathrm{s})$ & $(\mathrm{km} / \mathrm{s})$ & $(\%)$ & $(\mathrm{km} / \mathrm{s})$ & $(\mathrm{km} / \mathrm{s})$ & $(\%)$ & \\
\hline \multirow{3}{*}{$\begin{array}{c}\text { Hill } \\
\text { average }\end{array}$} & A & \#1065R006 & 7.28 & 6.51 & 11.2 & 9.72 & 4.10 & 3.88 & 5.3 & 4.01 & 3.63 & 10.0 & 0.38 \\
\hline & B & \#1064R012 & 7.26 & 6.55 & 10.4 & 8.85 & 4.11 & 3.83 & 7.0 & 3.94 & 3.76 & 4.6 & 0.35 \\
\hline & $\mathrm{C}$ & $\# 1066 \mathrm{R} 013$ & 8.15 & 5.94 & 31.3 & 35.99 & 4.55 & 3.35 & 30.3 & 4.09 & 3.15 & 26.0 & 1.38 \\
\hline \multirow{3}{*}{$\begin{array}{l}\text { Voigt } \\
\text { average }\end{array}$} & A & \#1065R006 & 7.89 & 6.96 & 12.6 & 9.15 & 4.55 & 4.35 & 4.3 & 4.46 & 4.07 & 9.2 & 0.39 \\
\hline & B & $\# 1064 R 012$ & 7.89 & 6.99 & 12.2 & 7.66 & 4.56 & 4.28 & 6.3 & 4.39 & 4.22 & 4.0 & 0.34 \\
\hline & $\mathrm{C}$ & \#1066R013 & 8.65 & 6.12 & 34.2 & 33.61 & 4.89 & 3.71 & 27.5 & 4.43 & 3.48 & 23.9 & 1.41 \\
\hline \multirow{3}{*}{$\begin{array}{c}\text { Reuss } \\
\text { average }\end{array}$} & A & \#1065R006 & 6.61 & 6.02 & 9.3 & 10.96 & 3.59 & 3.35 & 7.0 & 3.50 & 3.13 & 11.3 & 0.37 \\
\hline & B & $\# 1064 R 012$ & 6.58 & 6.07 & 8.0 & 10.81 & 3.60 & 3.30 & 8.7 & 3.42 & 3.23 & 5.6 & 0.37 \\
\hline & $\mathrm{C}$ & \#1066R013 & 7.61 & 5.74 & 28.0 & 39.56 & 4.17 & 2.95 & 34.2 & 3.74 & 2.78 & 29.5 & 1.37 \\
\hline
\end{tabular}

